\title{
60 Years of March and Simon's Organizations: An empirical examination of its impact and influence on subsequent research
}

DOI:

10.1111/joms. 12531

\section{Document Version}

Accepted author manuscript

Link to publication record in Manchester Research Explorer

Citation for published version (APA):

Wilden, R., Hohberger, J., Devinney, T. M., \& Lumineau, F. (2019). 60 Years of March and Simon's Organizations: An empirical examination of its impact and influence on subsequent research. Journal of Management Studies, 56(8), 1570-1604. https://doi.org/10.1111/joms.12531

\section{Published in:}

Journal of Management Studies

\section{Citing this paper}

Please note that where the full-text provided on Manchester Research Explorer is the Author Accepted Manuscript or Proof version this may differ from the final Published version. If citing, it is advised that you check and use the publisher's definitive version.

\section{General rights}

Copyright and moral rights for the publications made accessible in the Research Explorer are retained by the authors and/or other copyright owners and it is a condition of accessing publications that users recognise and abide by the legal requirements associated with these rights.

\section{Takedown policy}

If you believe that this document breaches copyright please refer to the University of Manchester's Takedown Procedures [http://man.ac.uk/04Y6Bo] or contact uml.scholarlycommunications@manchester.ac.uk providing relevant details, so we can investigate your claim.

\section{OPEN ACCESS}




\title{
60 Years of March and Simon's Organizations: An empirical examination of its impact and influence on subsequent research
}

\author{
By \\ Ralf Wilden \\ Macquarie Business School \\ Macquarie University \\ 4 Eastern Road \\ NSW 2109, Australia \\ Ralf.Wilden@mq.edu.au
}

Jan Hohberger

Ramon Llull University, ESADE Business School

Av. de Pedralbes, 60-62, 08034

Barcelona, Spain

Jan.Hohberger@esade.edu

Timothy M. Devinney

Alliance Manchester Business School

University of Manchester

Booth Street West

Manchester M15 6PB

Timothy.Devinney@manchester.ac.uk

\author{
Fabrice Lumineau \\ Krannert School of Management \\ Purdue University \\ West Lafayette, IN 47907-2056, USA \\ Lumineau@purdue.edu
}

Forthcoming in the Special Issue in the Journal of Management Studies: "Commemorating the 60th anniversary of March and Simon's “Organizations” 


\title{
60 Years of March and Simon's Organizations:
}

\section{An empirical examination of its impact and influence on subsequent research}

\begin{abstract}
We provide an analytic and systematic review of the impact of March and Simon's seminal Organizations on management research and discuss the book's value for current research and propose future applications of it. Building on bibliometric and text-mining approaches, our empirical analysis reveals that although Organizations was contextually based in the industrial milieu of the 1950's, its concepts have found ongoing resonance with scholars. Further, we find that much of this resonance appears to be driven by the ability of scholars in different 'schools of thought' to find useful insights from March and Simon's generalized theoretical structure. However, we also observe that scholars have been selective in their usage of ideas from the book over the last 60 years. Based our analysis, we propose a particular set of future research areas, including a focus on new organizational forms and extending March \& Simon's ideas to multilevel research, which can benefit from more holistically drawing on Organizations and connect its original ideas to address current management problems.
\end{abstract}

Keywords: Bibliometric, Coupling, Herbert Simon, James March, Organizations, Text Mining, Future of Work, Innovation 
"A classic is a book which has never exhausted all it has to say to its readers."

Italo Calvino, Why Read the Classics?

\section{INTRODUCTION}

James March and Herbert Simon's (1958) Organizations (hereinafter $M \& S$ ) is one of the most seminal publications in business and management, having been voted the seventh most influential management book of the $20^{\text {th }}$ century (Bedeian and Wren, 2001). The initial publication, along with newer editions, has been cited more than 29,000 times (as of August 2019) according to Google Scholar. Together with Simon's (1947) Administrative Behavior and Cyert and March's (1963) A Behavioral Theory of the Firm, $M \& S$ laid the foundation of the Carnegie School (Gavetti et al., 2007). At the same time, similar to other work emerging from the Carnegie School, $M \& S$ has been criticized for its generality (Gavetti et al., 2012; Gavetti et al., 2007) and obvious propositions (Weick, 2017). However, despite $M \& S$ 's perceived and anecdotally discussed impact on subsequent management research, there is a lack of comprehensive and systematic reviews of its content and impact on business research. The various traditional narrative based reviews of Administrative Behavior and A Behavioral Theory of the Firm (Argote and Greve, 2007; Dosi and Marengo, 2007; Gavetti et al., 2012; Gavetti et al., 2007) focus largely at looking at the larger impact of the Carnegie School. The only direct review of $M \& S$ by Weick (2017) is predominantly a personal reflection.

Taking its significant impact on subsequent research into account, while accounting for criticisms as well, we aim to provide a broader, more detailed, and systematic analysis that better encompasses the wide scope of $M \& S$ and how it has inspired the research that followed its initial publication. In line with Makadok et al. (2018), we offer a critical perspective on the theoretical 
arguments advanced by $M \& S$ regarding: levels of analysis (the who?), phenomena (the where?), and boundary conditions (the when?). To do so, we structure our discussion in two parts, beginning with 'taking stock' of $M \& S$, followed by our 'moving forward' discussion, in which we outline that $M \& S$ is still relevant for a significant array of applications in the study of organizations, and how future scholarship can be enhanced by building on $M \& S$ 's original ideas. In doing so, we attempt to take into account the context and time period in which $M \& S$ was written, and how its relevance and use by scholars changed as the business and management environment changed in the intervening 60 years.

From a methodological perspective, the diverse nature and wide impact of $M \& S$ make it difficult to provide an inclusive and transparent review (Denyer and Tranfield, 2009) using a traditional narrative review approach. Traditional narrative reviews are very flexible due to their less formalized method (Hammersley, 2001), but they tend to rely on a more limited number of studies (Rousseau et al., 2008) and are often criticized because of their potential bias and lack of both transparency and reproducibility (Denyer et al., 2008). Furthermore, there is often a bias associated with traditional literature reviews and expert surveys as they are conducted based on the (conscious and subconscious) assumptions and perspectives of the review team (RamosRodriguez and Ruiz-Navarro, 2004). To borrow from $M \& S$ 's concept of bounded rationality, the sheer volume of relevant publications combined with the diversity of fields from which they originate (spanning management, strategy, psychology, sociology, and economics) exceeds the capabilities of the best review team. Due to the size and diversity of $M \& S$ 's impact, this limitation would be particularly salient for any traditional narrative review, as a review team would have to focus and limit its analysis to particular aspects. To address concerns of inclusivity and transparency (Denyer and Tranfield, 2009), we combine two complementary 
empirical methods. We use bibliometric coupling with network analysis to identify research streams in the form of related publications based on the structure of their references. Further, we apply text mining, which allows us to identify central concepts and themes in each research stream and to map their evolution over the last 60 years. By using text mining, we shift the level of analysis from publications, and their citations, to the actual content of each publication.

Our review is structured as follows. First, we introduce $M \& S$ by summarizing the book using text mining to identify its conceptual and thematic underpinnings as they are revealed by the words and language used by $M \& S$, without any presupposition as to concepts and theories therein. Second, we then focus our attention on the scholarship that has followed on from $M \& S$, again without any preconception that might be biased by our imposing a structure on that work. To do so, we use bibliometric coupling analysis to isolate key research streams and their most representative publications followed on from $M \& S$, aggregating them into clusters that represent coherent 'schools of thought'. Third, we examine these research streams with text mining to identify the key thematic underpinnings of each research stream, paying particular attention to their evolution. As such, our analytic approach did not focus on a set of key concepts we a priori identified as important but rather we derived concepts from the literature's subsequent use of the book. Fourth, we compare how these 60 years of research have built on the themes and concepts that we uncovered in the original manuscript. Finally, building on a discussion of how $M \& S$ has withstood the test of time, we provide suggestions for future research.

\section{METHODOLOGY}

\section{Data}

Our analysis is based on two main data sources: the book $M \& S$ itself and the journal publications that cite $M \& S$. The core data in the first instance were the text of $M \& S$; suitably converted into 
machine readable format, corrected for consistency and errors, and with the bibliography deleted. In the second step, we created a database of all journal publications that cite $M \& S$. This was done by retrieving all publications (known as focal publications) citing the book from the ISI Web of Science (WoS) database in June 2017. We did not limit the search to specific journals or research areas (as frequently done in reviews) as we were interested in the overall impact of the book and its diverse nature. WoS is particularly suitable as it provides accurate and machinereadable bibliographic data on older publications via passive listing. Also, as common practice in most bibliometric reviews (e.g., Randhawa et al., 2016; Vogel and Güttel, 2012), we restricted our search to English-language articles only and excluded books and book chapters from our sample. This selection criteria led to an initial sample of 5,168 articles citing $M \& S$.

In the next step, we downloaded the abstracts for all citing articles. However, as WoS did not list abstracts for articles before 1988, we had to complement our WoS data with abstracts retrieved through Scopus. Overall, we obtained $99 \%$ of abstracts for our analysis. Finally, to enable the bibliometric analysis and to provide a meaningful analysis of the relatively long analysis period of 60 years, we followed previous empirical reviews (Ramos-Rodriguez and Ruiz-Navarro, 2004; Randhawa et al., 2016) to split the data in four equal fifteen-year time periods: 1958-1972 (324 articles), 1973-1987 (1,226 articles), 1988-2002 (1,417 articles), and 2003-2017 (2,201 articles).

\section{Coupling and network analysis}

We use bibliographic coupling as a quantitative method to map and analyze scientific research, which has shown its usefulness in earlier management reviews (Devinney and Hohberger, 2017; Vogel and Güttel, 2012). Coupling provides a proximity score, which approximates the closeness between two publications by measuring the shared number of references between two documents 
(Kessler, 1963). We then used the proximity scores to create a network representation of the publications citing $M \& S$. The network approach to analyzing publications or references has become increasingly popular within bibliometric studies (e.g., Randhawa et al., 2016; Vogel and Güttel, 2012; Wilden et al., 2018). It possesses several advantages compared to classical clustering methods (e.g., clustering or multi-dimensional scaling), including allowing for the direct visualization of the relationships between publications (Randhawa et al., 2016), being more precise and effective (Zupic and Čater, 2015), and offering improved visual depictions for a larger numbers of publications (Vogel and Güttel, 2012).

We visualized the network with the Force Atlas algorithm implemented in the Gephi software (Jacomy et al., 2011). It estimates the position of a publication in the network by the proximity scores of the connections and the path length between publications. Next, we applied the Louvain modularity optimization to detect communities (clusters and streams of research) within the network (Blondel et al., 2008). ${ }^{\mathrm{i}}$ The number of resulting communities can be modified using a resolution coefficient (Lambiotte et al., 2008). We varied the resolution coefficients in an iterative fashion to optimize the quality of the cluster solutions (we only considered solutions with a modularity above 0.4 ) and to identify meaningful clusters. We also generated centrality measures for all publications. These are shown and explained in the Online Appendix.

\section{Text mining}

For the text mining part of our analysis we used the Bayesian learning algorithm implemented in Leximancer (Randhawa et al., 2016; Wilden et al., 2016). This approach allowed us to examine the words used by authors to conduct conceptual (thematic) and relational (semantic) analysis of the book and abstracts (Rooney, 2005). We investigated common text elements (concepts) and groupings of revealed text elements (themes). The algorithm automatically picks the best fitting 
number of themes contingent on the recognized concepts and permits overlapping of clusters of themes. This approach is especially suitable to our review. Previous research has found the results to be highly reproducible and the concept identifications and the clustering to be reliable, leading to a reduced risk of biases often inherent in manually coded text (Dann, 2010; Smith and Humphreys, 2006). Furthermore, this approach exhibits high face and correlative validity (see, e.g., Grech et al., 2002). We used the scanned and converted version of $M \& S$ and the respective abstracts of articles citing $M \& S$ as inputs into our analyses. We opted to merge word variations (e.g., 'organization' and 'organizational') and used an integrated stop word list (e.g., 'is', 'just'). Subsequently, the algorithm generates concept seeds "automatically using a ranking algorithm for finding seed words that reflect the themes present in the data. This process looks for words near the center of local maxima in the lexical co-occurrence network" (Smith, 2003, p. 23). The algorithm begins with a concept seed and widens the description to discover additional words (e.g., synonyms and modifiers), which carry comparable meaning. A weighting is then applied to the concept seeds, which is based on the frequency with which the seeds appear in sentences and is compared to how often the concept seeds appear in other parts of the abstracts. We used the standard learning threshold settings, opted to exclude name-like concepts (i.e., words starting with a capital letter) and limited the total number of concepts to be discovered to 60 .

The outcome of this process step is the creation of an automatically generated dictionary containing relevant concepts. After close inspection of this list, we deleted concepts that did not carry significant meaning in our setting (e.g., 'respondent', 'publication'). Subsequently, using the text-derived dictionary, the data is marked with the identified concepts to a two-sentence resolution, and a concept is found to appear in a sentence block if sufficient amassed evidence (i.e., the sum of the weights of the keywords) is found. The results are represented as plots of the 
concepts in a semantic network via the application of an asymmetric scaling algorithm and the concept co-occurrence incidences are used to rank the concepts by their connectedness (map or meaning). Accordingly, both the frequency with which concepts occur, as well as the proximity with which they co-occur in the text, is investigated, resulting in "entity concepts [being] clustered according to weight and relationship, to create a concept cluster map" (Grech et al., 2002, p. 1719). Themes in the maps are represented by circles, comprising multiple concepts, and their color indicates the importance of the respective theme (i.e., the brighter, redder the circle, the more frequently the grouped concepts are mentioned in the data). The distance of the concepts and themes on the maps represents their degree of semantical relatedness (Campbell et al., 2011; Rooney, 2005). Lastly, we examined the maps of meaning and their statistical information and confirmed their stability by repeating the above procedure multiple times.

\section{THE ORIGINAL PUBLICATION OF M\&S}

In this section, we analyze the content of $M \& S$, which will serve as the benchmark for the subsequent analysis of articles citing the book to identify its influence over the last 60 years. To do so, we do not use our own reading or interpretation but let the book itself 'speak' via machine-based text-mining identification of the core concepts and themes and their relationships.

Figure 1 shows the output for the entire book (excluding the preface and postscript). In the discussion of the text mining results throughout the remainder of this paper, words in italics refer to identified themes, and words in inverted commas represent identified concepts. We can see that $M \& S$ focused on the interaction between the individual (bright red) and the organization (red-brown color), both representing the most central themes. The organization theme comprises the concepts 'behavior', 'problem', and shares the concept 'decision' with the individual theme. The individual theme overlaps with the alternative theme with concepts such as 'consequences' 
and 'conflict', indicating a discussion about the outcomes of individual decision-making. Notably, individual perceptions (the theme perceived) appear to be important in this context. Furthermore, decision-making is an important area, as indicated by the theme decision alternatives, which comprises concepts such as 'decision-making', 'goals', and 'alternatives'. Some discussion also revolves around the action that results from decision-making. Relatively less attention was given to group dynamics (green color) and system aspects of decision-making.

INSERT FIGURE 1 HERE

As $M \& S$ discuss distinct aspects of organizations in different parts of the book, we textmined the book by chapters. Table I shows the breakdown of themes and concepts by chapter. We can see that Chapter 1 provides an overview of organizations, discussing their importance, and ends with the introduction of several propositions, which are further developed in the remainder of the book. The theme organizations comprises concepts such as 'behavior', 'human' and 'influence'. They set out the reason for the book as "psychology and sociology textbooks do not devote even a short chapter to the subject of formal organizations" (p. 2).

INSERT TABLE I HERE

In Chapter 2, the discussion remains focused on organizations, this time deliberating relevant 'processes' and their purpose. There is also a detailed discussion on the history of organizational theory, focusing on Taylor's scientific management (as indicated by concepts such as 'human', 'production', 'fatigue' and 'worker') and, to a lesser extent, theories of departmentalization (as indicated by concepts such as 'departmentalization', 'formal' and 'theory'). 
Chapters 3 to 5 discuss how motivations and goals influence human behavior in organizations, thereby adding to 'classical' organizational theory by viewing the employee as more than simply a passive instrument within the organization. In Chapter 3, the discussion focuses on the individual motivation to produce and, to some extent, covers how the environment influences organizations. Consequently, several existing models of control such as the Selznick and Merton models are introduced. Furthermore, the individual is discussed in more detail, including a discussion about satisfaction, as well as the theme alternatives comes up, preparing Chapter 4 "where the decision to participate in (or leave) the organization is discussed" (p. 53).

Chapter 4 concentrates on the individual participant's motivation to contribute to the organization. A detailed discussion is on inducements (as shown by the theme inducements and concepts such as 'inducements-contributions'), which are defined as “"payments' made by (or through) the organization to its participants (e.g., wages to a worker, service to a client, income to an investor)" (p. 84). Principal participants influence the equilibrium of the organization and are identified as: employees, investors, suppliers, distributors, and consumers. The emphasis here is on employees, with a discussion of the factors that lead to 'satisfaction' and perceived ease to move (i.e., 'movement' and 'turnover') and the availability of job alternatives.

Chapter 5 discusses 'conflict' in organizations, which are categorized into individual decision-making conflict, conflict within organizations, and interorganizational conflict. This chapter dominantly addresses organizational conflict (see also the bright red color of the theme organization comprising the concept 'conflict'). Accordingly, we see themes such as decisionmaking, goals, and bargaining mattering more materially. $M \& S$ also gives a detailed discussion about the difference in goals as a contributor to intergroup conflict within an organization. The theme pressure appears in this chapter, discussing factors that give "rise to a pressure toward 
participation in the relevant decisions made by other participants and thus to pressure toward joint decision-making" (p. 122). In terms of organizational reaction to conflict, four strategies are mentioned: problem-solving, persuasion, bargaining, and 'politics'. 'Game' theory is discussed in the context of bargaining.

In Chapter 6, $M \& S$ elaborates on rational decision-making as a limitation to existing organizational theory. Consequently, they discuss satisfactory vs. optimal standards when assessing alternatives. They discuss how different environmental situations (as perceived by organizational members) lead to different sets of organizational responses, which they term the performance program, which may be adaptive to a large number of stimuli. They give attention to the issue of communication and coordination and state that the "capacity of an organization to maintain a complex, highly interdependent pattern of activity is limited in part by its capacity to handle the communication required for coordination" (p. 162). In this context, uncertainty absorption through communication is meant to achieve coordination between units. This final part provides a brief discussion on organizational 'structure' and its impact on behavior.

In the final Chapter 7, Organization looks at 'innovation' in organizations. $M \& S$ starts by differentiating between continuation of a program vs. 'change' in a 'program' of action. Change in program, that is, innovation, often creates costs that are difficult to estimate, leading to the tendency of individuals to prefer program continuity. They stress that a 'theory' of 'choice' of persistence vs. change needs to also discuss 'action' vs. inaction, and also consider the environmental 'conditions' in 'decision-making' (see theme decision). Then, attention is shifted towards the process of innovation, which is linked to 'problem-solving'. After discussing aspects of innovation (e.g., timing and institutionalization of innovation, non-programmed decisionmaking, group problem-solving), $M \& S$ moves on to consider the various organizational levels 
and their relationships to innovation. In this context, the authors refer back to goals. Finally, the process of 'planning' is discussed, referring back to the price mechanism to direct decisions.

\section{THE INFLUENCE AND IMPACT OF M\&S}

We now turn our attention to the research that has built on $M \& S$. We start our analysis with a description of the research areas that have drawn on $M \& S$. Table II categorizes the publications building on $M \& S$ across all scientific fields (Panel A), as well as within Business and Economics (Panel B). ${ }^{\text {ii }}$ Overall, the book has had a recognizable impact across a wide range of fields, but, not surprisingly, most research has been published in Business and Economics, followed by Psychology. While the relative number of publications citing $M \& S$ in Psychology has remained relatively constant (between 10\%-12\%), its use in Business and Economics has become more dominant over time, increasing from $38 \%$ of all publications in the period $1958-1972$ to $52 \%$ in the period 2003-2017. It is also important to note that the absolute number of publications has increased across most all scientific fields - with the notable exceptions of Sociology and Government and Law. However, $M \& S$ is a book whose appeal was, and remains, dominantly concentrated around Business, Management, Economics, and Psychology. A table highlighting the top 50 publication outlets can be found in the Online Appendix.

INSERT TABLE II

\section{FOCAL CONCEPTS AND THEMES IN WORK CITING $M \& S$}

Next, we show the results of the coupling and network analyses to identify citing clusters in publications building on $M \& S$. We compare four equal-sized time periods to analyze the evolution of the relevant research. Figures $2 \mathrm{a}, 3 \mathrm{a}, 4 \mathrm{a}$, and $5 \mathrm{a}$ depict the results of the couplingbased network analysis and Table III shows the most cited (i.e., most important publications in 
each cluster) and the most representative publications for each cluster based on their closeness centrality (a complete list of all publications within each cluster, including the associated network centrality statistics, can be found in the online Appendix). To keep the paper succinct, we show the labels for a number of particularly relevant publications in the network graphs and only the Top 3 publications in Table III. Based on the coupling results, we use text mining to investigate whether the research using $M \& S$ 's concepts and themes differed across time periods and across respective clusters of research. To do so, we use the cluster membership of each article as identified in the previous analyses and conduct thematic analysis per period (Figures $2 b, 3 b, 4 b$ and $5 b)$. Clusters are identified by $\#_{t}$, where \# indicates the cluster and the time period: $1=1958-1972,2=1973-1987,3=1988-2002$, and $4=2003-2017$.

\section{INSERT FIGURES 2-5 AND TABLE III HERE}

In the first time period, 1958-1972, the coupling analysis identified 7 clusters. However, given the small number of publications in two of these clusters $(n<3)$, we only analyzed the text of five clusters. Cluster $1_{1}$ is closely related to research on 'individual' career development and how individuals identify their role in commitment to the organization (e.g., Hall et al., 1970; Hrebiniak and Alutto, 1972), whereas the work of Katzell and colleagues (1961) (Cluster 51) discusses job satisfaction and employee turnover. Cluster $4_{1}$ discusses topics of conflict (Pondy, 1967; Schmidt and Kochan, 1972; Walton and Dutton, 1969) and the contingency strategy approach to organizational theory (Hickson et al., 1971), as indicated by the concept 'contextual'. Finally, Cluster $3_{1}$ is dominated by the work of Perrow (1967), with its well cited comparative analysis of organizations, and Hage \& Aiken's (1969) early discussion of routines and their link to organizational 'structures' and goal setting. 
In the second time period, 1973-1987, we can see that the publications in Cluster $1_{2}$ relate to communication and R\&D in an innovation setting. This includes discussions on organizational structure and influential work on boundary spanning (Tushman, 1977), but also more general work on information processing, which is closely connected to the center of the network (e.g., Daft and Lengel, 1986; Daft and Weick, 1984). Additionally, in the text mining results, we see that this research also emphasizes the role and the characteristics of individuals. Cluster $2_{2}$ comprises publications that focused on process-oriented organization theory (e.g., Burgelman, 1983; Fredrickson, 1984; Ireland et al., 1987), work that revolves around topics such as organizational structure (e.g., Miller, 1987) and 'decision'-making (e.g., Huber and McDaniel, 1986; Shrivastava and Grant, 1985) in the context of organizational 'change' and evolution. It is also noteworthy that seminal work on institutional theory (DiMaggio and Powell, 1983) and upper echelon theory (Hambrick and Mason, 1984) are located in this cluster. What is interesting to note is that while these papers have been influential - i.e., well cited - they are less representative of the overall cluster - they possess low centrality. Similarly, in Cluster $3_{2}$, the most cited article is Meyer and Rowan (1977), which discusses organizational structures as myths and ceremony, but it is not actually representative of this very diverse cluster. Cluster $4_{2}$ is similar to Cluster 5 , with its concentration of research on "employees" role in the organization, including job 'satisfaction' and 'turnover' (e.g., Mowday et al., 1979; Steel and Ovalle, 1984) and 'commitment' (e.g., Angle and Perry, 1981; Bateman and Strasser, 1984; Eisenberger et al., 1986); themes which also clearly appear in the text mining analysis. While Cluster $5_{2}$ is relatively diverse, and importantly includes work on transaction cost economics (e.g., Williamson, 1981) and 'decision' 'process' (e.g., Simon, 1979), it is largely centered around 'behavior', most obviously culminating in the behavioral theory of the firm. This group includes 
work on managerial risk taking (March and Shapira, 1987), organizational 'change' (March, 1981), control (Lord and Kernan, 1987), and rational 'decision' making (Simon, 1979). Overall, it should be noted that Clusters $1_{2}, 2_{2}$ and $5_{2}$ are connected, with significant conceptual overlaps. On the other hand, Cluster $4_{2}$ is clearly separated and quite distinct from the other research utilizing $M \& S$. This is mirrored by the text mining results, where cluster $4_{2}$ with its focus on 'turnover', 'commitment', and 'satisfaction', is distant from the remaining network and the concepts 'organizational', 'information', 'performance', and 'decision' are most central.

In the third time period, $1988-2002$, publications in Cluster $1_{3}$ largely center on issues around 'environmental' fit' and contingency approaches in the context of competitive strategy (Miller, 1992, 1993), configurations of inter-organizational relationships (Bensaou and Venkatraman, 1995), environmental munificence (Castrogiovanni, 1991), and strategic fit at the business unit level (Govindarajan, 1988). Cluster $1_{3}$ represents an organizational 'behavior' cluster with a relatively strong focus on 'risk'-taking, including Greve's (1998) work on aspiration and risk, March and Shapiro's (1987) research on risk preferences and attention, Sitkin and Pablo's (1992) publication on the determinants of risk taking, and Bromiley's (1991) study on the relationship between risk taking and corporate performance. We see also that Cluster $2_{3}$ is closely related to Cluster 53, which includes research on 'top' 'managements' team 'decision', such as upper echelon research and demographics (Finkelstein and Hambrick, 1990; Wiersema and Bantel, 1992), extending the work by Hambrick and Mason (1984) that appeared in time period 2. This cluster also includes research on search, innovation and 'change' (Gavetti and Levinthal, 2000; Henderson and Clark, 1990; Van de Ven and Poole, 1995). The text mining analysis also shows the close colocation of Clusters $1_{3}$ and $4_{3}$, with the associated concepts of 'top', 'management', 'decision', 'cognitive', 'change', and 'behavior'. Cluster $5_{3}$ is connected to 
Cluster $3_{3}$, where we see 'innovation', learning, 'search', and respective 'capabilities' forming the core concepts and themes. This cluster includes research on search and non-local search (Fleming, 2001; Fleming and Sorenson, 2001; Rosenkopf and Nerkar, 2001) and learning specific capabilities and dynamic capabilities (Zollo and Winter, 2002) - often in the context of interorganizational relationships (Dyer and Singh, 1998; Zollo and Winter, 2002) - and studies on the challenges of knowledge transfer (Szulanski, 1996). At the center of this cluster is research on evolution and change; for example, on the topics of renewal (Barr et al., 1992; Boeker, 1997; Huff et al., 1992), reorientation (Lant et al., 1992), and transformation (Miner et al., 1990). In the text mining graph, Clusters $5_{3}$ and $3_{3}$ are less connected. However, the text mining results of Cluster $3_{3}$ are very representative of the associated articles ('knowledge', 'interorganizational', 'innovation', 'capabilities' and 'governance'). Finally, Cluster $4_{3}$ represents the continuation of scholarship on job turnover and commitment (Einsenberger et al., 1997; Mitchell et al., 2001; Settoon et al., 1996). Overall, it is worth noting that based on the text mining results, 'strategic' concepts became more dominant during the period 1988-2002.

In the most recent time period, 2003-2017, the coupling analysis identifies five clusters. In Cluster $1_{4}$, we find publications that relate to innovation, knowledge, and search, as evidenced not only by the Top 3 articles but also in the other relevant work (Fleming and Sorenson, 2004; Nerkar, 2003; Rosenkopf and Almeida, 2003). We can see that Cluster $1_{4}$ is closely linked to the concepts 'innovation', 'knowledge' and 'external' 'capacity', indicating that the papers in this cluster discuss the themes of market opportunities and knowledge. Publications in Cluster $2_{4}$ focus on routines and change (Becker, 2004), absorptive capacity routines (Lewin et al., 2011), and routines (Parmigiani and Howard-Grenville, 2011). Accordingly, the text mining results show the key theme as routines, together with the concept 'change'. Cluster 24 is closely related 
to Cluster 44, which comprises publications related to the Neo-Carnegie School (Gavetti et al., 2007; Powell et al., 2011), as well as research on inertia (Gilbert, 2006), aspiration (Baum and Dahlin, 2007), and slack (Daniel et al., 2004). Cluster 44 is also related to the capabilities, routines, and organizational themes, which share the 'learning' and 'change' concepts. The organizational theme further comprises the concepts 'behavioral', 'process', 'management', and 'performance', the latter ones sharing with the firm theme. Cluster 34 represents a general human resource management cluster (Allen et al., 2003; Felps et al., 2009; Holtom and O’Neill, 2004) and has again a strong emphasis on turnover and motivation related publications. This is also reflected in the cluster's location within the job theme, which comprises the concepts 'voluntary', 'turnover', and 'embeddedness'. Finally, Cluster $5_{4}$ is closely linked to the firms and search themes (McEvily and Marcus, 2005; McEvily et al., 2003; Moran, 2005) and social capital (De Carolis and Saparito, 2006; Villena et al., 2011).

\section{DISCUSSION: HOW RELEVANT IS M\&S TODAY?}

We structure our discussion in two parts. First, we 'take stock' of our findings and highlight some areas where scholars have made limited use of $M \& S$. We then 'move forward' by providing suggestions about how ideas from $M \& S$ could contribute to future research in areas such as organizational structure and control; individuals; and change and innovation. Thus, our discussion is grounded in and extends the preceding empirical analysis.

\section{Taking stock}

$M \& S$ not only has a continuing and sustaining influence but even a growing influence, receiving four times more citations over the period 2003-2017 than over the period 1958-1972. A reason for this appeal is that the book combines diverse and fundamental conceptual insights within management, including human motivations, decision-making, and organizational imperatives - 
all topics that have been at the core of business and management scholarship, with varying degrees of emphasis, over the last six decades. $M \& S$ has the ability to speak to scholars from many disciplines in management - from organizational theory and behavior, strategy, and supply chain management - as well as other social sciences, particularly psychologists and economists. In addition, the work has spoken to different generations of scholars, albeit in different forms as topical areas waxed, waned, and were reborn. It is, therefore, no surprise that we find the book's widespread influence on several research fields in our coupling analysis (as seen in Figures 2a, 3a, 4a, and 5a). Our findings are in line with Weick (2017, p. 1), who states that " $[\mathrm{t}]$ he context in which 'Organizations' first appeared was one of diffuse social science that was being consolidated and gaining momentum." At a time when scholarly journals were not well developed yet, the book synthesized many ideas about organizations.

To add precision to these observations, we conducted analysis of the complete text of $M \& S$, which shows that around the core theme of $M \& S$ we see three groupings of ideas. The first concentrates on the themes of group, system, and production. The second is related to the themes of action, alternative and individual. The third is associated with the themes of change, activity and program. It is interesting how the subsequent literature has only peripherally picked up on these distinctions, as nearly all of the coupling clusters link back to a limited number of narrow themes and concepts. Examining Figures $2 b, 3 b, 4 b$, and $5 b$, we see that only four of the clusters $-1_{1}, 5_{3}, 0_{4}$, and $5_{4}-$ meaningfully link to more than one thematic area. This is reflective of scholars using $M \& S$ to build on relatively narrow areas of research; having then selected specific concepts from $M \& S$ to provide weight to their theorizing and justification. While some scholars used $M \& S$ in its totality, it has been more likely that scholars chose those parts of $M \& S$ that assisted them in their existing or emerging area of work. One proposition that follows from this 
is that, perhaps, $M \& S$ has served primarily as an evolutionary impetus that helped scholars do what they were going to do anyway, but do it better, faster, and more parsimoniously.

Matching the book's content with how citing publications have used these ideas over time, our analysis shows that while some concepts and themes emerging from $M \& S$ have increased in attention over time, others have become less important, lending support to the view that $M \& S$ were not just describing a current context but where sufficiently robust in their conceptualization to incorporate potentially new and evolving ideas that they anticipated might be important in the future. The first period (1958-1972) following the publication of $M \& S$ saw work relating to industrial jobs (Cluster $5_{1}$ ), technology and industry structure (Cluster $3_{1}$ ), subunits of organizations and conflict (Cluster $4_{1}$ ) and much more general work on the role of the individual as more than just a tool of the organization (Cluster $\left.1_{1}\right)$. By the final time period (2003-2017), we see a very different pattern. Clusters 24 and 44 reflect related work on routines, with the former addressing routines and change and the latter routines, learning and organizational structure. Cluster $1_{4}$ and 54 relate to knowledge, with the latter linking social search to firms, while the former concentrates on scholarship linking knowledge to innovation and opportunities. The intermediate time periods (1973-1987 and 1988-2002) are interesting in that they reveal how $M \& S$ was used to support and buttress research relating to strategy, structure, effectiveness, performance, and fit (Clusters $3_{2}$ and $5_{2}$ in the second period and cluster $1_{3}$ in the third period), the rising importance of cognition and its relationship to change (Clusters $2_{3}$ and $5_{3}$ ), and the emerging work on top management teams (Cluster $2_{2}$ ) and later that on governance (Cluster $3_{3}$ ). As highlighted by the coupling and text-mining analyses, the only real area of work that consistently utilized $M \& S$ over the 60 -year period was that relating to employment and jobs. This analysis further highlights how subsequent research has built on and 
borrowed ideas from $M \& S$ even though their key ideas were not part of $M \& S$. For example, the terms routine and capabilities did not appear as central themes or concepts in $M \& S$ in our analysis; however, research within the capability view of the firm are relevant in Cluster $4_{4}$. On the other hand, some themes and concepts central to the book became less relevant to the later discussion. For example, the theme/concept of conflict, while central to the book and Period 1, does not appear in the later periods in our analysis.

Interestingly, our analysis of the forward citations led to the impression that research on global, service-oriented, internet-enabled, social media driven features of business activities, with its reliance on looser organizational forms and more individual-by-individual labor structures (e.g., Cirillo et al., 2018), has tended to not pick up on $M \& S$. In addition, new technologies have changed the way individuals and organizations interact and contract with each other and given rise to greater economic representation of entrepreneurial firms supported by private equity and venture capital structures. To further investigate this observation, we collected various publication samples related to new organizational forms and compared the citation ratio of $M \& S$ in theses samples to the citation rate in two control samples. We used five samples to approximate the very diverse research around new organizational forms: 1) business model innovation, 2) ecosystems, 3) platforms, 4) blockchain, and 5) industry 4.0. While none of these samples individually can provide a complete picture on the use of $M \& S$ within recent research on new organizational forms, the combination of the different samples provides an overall indication of its use related to new organizational forms. To control for the citation rates, we generated samples in research on "industrial organization" and in "general management". In each case, we focused on publications within management and business journals and the most cited publications (max. 2,000 publications). The results shown in Table IV clearly indicate that $M \& S$ 
is far less cited in the area of new organizational forms than in our general management sample. The fractional citation rates ( $M \& S$ citation rate per overall references) for the new organizational forms ranges from $0.000 \%$ to a maximum of $0.015 \%$ for the platform sample. In comparison, the fractional citation rate for the control sample (general management) is $0.72 \%$; nearly five times higher as the in the most citing sample for new organizational forms.

INSERT TABLE IV HERE

Thus, we believe that research on new forms of organizing, such as internet and networkbased organizations, ecosystems, as well as the rise of decentralized ledgers supporting smart contracts as seen with blockchains, could benefit from integrating some of $M \& S$ 's propositions. $M \& S$ 's underlying logic of individuals having employment contracts and working within a clearly and formally defined hierarchical structure can be rethought to suit the importance of emergent organizations, such as communities of practice and open source software development (Puranam et al., 2014) and the greater importance of systems integration (Hobday et al., 2005)

\section{Moving forward}

Based on our analysis, we find that $M \& S$ has been, and still remains to this day, a critical source for any management scholar. As noted earlier, there are three major concentrations of ideas in $M \& S:$ (1) Organizational structure and control (Production, System and Group), (2) Individuals (Perceived, Individual, Alternatives, and Action), and (3) Change and innovation (Change, Activities and Program); therefore, we structure our discussion along these three issues. For $M \& S$, these were what the organization organized via the 'problems' it faced, the 'decisions' it made, and the 'behaviors' that it fostered. For $M \& S$, it was these interactions, not our separate understanding of each dimension, that was key to understanding the organization. Hence, future 
research could benefit from revisiting $M \& S$ 's foundational ideas but perhaps by doing so more holistically as we believe that a strength of $M \& S$ relates precisely to its integrative approach. Thus, we believe that there are several ways forward to extend $M \& S$ 's original ideas and its relevance to today's business environments.

Given that our findings highlight the limited impact of $M \& S$ on some contemporary research fields, we outline some suggestions for future research in regard to new organizational forms, innovation, and to extend $M \& S$ 's ideas to multi-level research (i.e., widen the level of analysis) (see Table $\mathrm{V}$ for sample research questions).

\section{INSERT TABLE V HERE}

\section{Organizational structure and control}

In line with Makadok et al.'s (2018) lever 3 of advancing theory ('Where'), we suggest that $M \& S$ 's ideas should be extended to the context of new organizational forms. For these phenomena, research can draw on important insights developed in the book that relate to the role of organizational structures and how they can help overcome the problems of division of labor and/or integration of effort. The importance of structure is especially relevant given the emerging new organizational form, such as the platform economy, which raises the question around value co-creation between platform or ecosystem partners (Wilden et al., 2017). Looking back at two of the core ideas in $M \& S$, namely compensation and incentives, raises important questions about how systems of compensation and incentives in ecosystems and platform-based economies should be structured and controlled. For example, platform organizations such as Uber do not employ the drivers directly, but rather provide employment contracts without fixed salaries. Conceptually, the nature of organizational structures is still paramount to understand these platform organizations but the structures and mechanisms that need to be put in place are very 
different from what is described by $M \& S$. For example, performance evaluation in such organizations has often become very open with public feedback contributing to the driver's (i.e., employee's) reputation. Similarly, websites such as Yelp provide public performance feedback mechanisms for organizations and their employees. Thus, future research is needed to understand the role of customers in the performance evaluation process. Consequently, $M \& S$ 's ideas may thus help to extend consumer-related research on access-based consumption and platforms enabling these services (e.g., Zipcar). Such research has found that besides formal control mechanisms to guide behavior, such as penalty systems and formal rules, the organization uses social control mechanisms 'enforced' by the brand community (Bardhi and Eckhardt, 2012).

The locus of competition and value creation has shifted from the individual organization to an ecosystem of organizations. Therefore, Boudreau and Lakhani (2013, p. 69) called researchers and industry alike to "put as much energy and intelligence into designing systems for organizing work outside company walls as we do for work within them." Our analysis shows that $M \& S$ 's ideas have continually been extended by citing authors to suit their research area. For example, research addressing new forms of organizing have extended the initial ideas to the context of alliances and inter-organizational collaborations, although these organizational forms were not part of the book. Along these lines, we see many opportunities for future research to update and extend $M \& S$ beyond the scope of the single organization; in particular to encompass new organizational forms and the challenges of Industry 4.0. The current trend of automation and data exchange, the 'Internet of Things', cloud computing, and cognitive computing invites to revisit some of $M \& S$ 's insights. Sako and Chondrakis (2017, p. 3), for instance, state that "the two strands of research, one on firm boundary and the other on intra-firm organization design, have been conducted in parallel without much connection between the two." 
An important idea suggested by $M \& S$, and further developed by later publications of the Carnegie School, relates to the importance of the relationship between organizational structures and decision-making. It has led many scholars to study how organizational structures guide the way information is processed and, in turn, how decisions are made. Many important research streams such as behavioral strategy, theories of attention, and cognitive perspectives have been influenced by this work and are influential in contemporary business research. $M \& S$ 's conceptual insights about the influence of organizational structures bear very important implications to understand the pattern of communications and relations both within and across firms. A recent example drawing upon this information-processing view of organizational structures is the study by Lumineau (2017) who applies this logic to the influence of contracts on trust development. He argues that the type of contract design - through its respective focus on controlling and coordinating aspects - induce specific calculative and non-calculative mechanisms behind the development of trust. We see and encourage future studies to extend this line of enquiry to further analyze, for instance, how the division and allocation of tasks, the provision of rewards and information, or the nature of goal setting and performance feedback influence how individuals recognize and notice potential issues (i.e., focus of attention), diagnose situations (i.e., problem representation and formulation), and search for solutions (i.e., deliberation and reflection) in the intrafirm and interfirm contexts.

\section{Individuals}

In line with Makadok et al.'s (2018) lever 2 of advancing theory ('Who'), we stress the importance of future research addressing the above issue of new forms of organizing by bringing together different levels of analysis; that is, linking the micro-level (individuals) with the mesolevel (organizations). Thereby, we believe that research can benefit from continuing to draw 
from, and thereby extending some of $M \& S$ 's ideas. New technologies continue to change the nature of work, and thus motivation and incentivization. Much of $M \& S$ focuses on individuals in organizational context who make decisions and engage in social behaviour. However, limited research has used a $M \& S$ perspective to focus on the individuals in these new forms of organizing. Organizational design aspects influence how boundedly rational individuals focus their scarce attention and interpret informational cues. Judgment and decision-making are influenced by organizational structures that guide selective attention to organizational issues. Organizational structures shape the nature of the actions taken by individuals to gather information when making decisions. That is why it seems particularly relevant to further combine the individual and organizational levels (Puranam et al., 2014).

An example of how $M \& S$ can inform multilevel issues is the impact of new organizational forms on the behaviour of and consequences for the individual employee (Randhawa et al., 2019). Opening firm boundaries has also affected traditional employment models, which requires reinterpretation of some of $M \& S$ 's core concepts, such as individuals' motivations, goals, decisions to contribute to or leave the organization, as well as employee turnover. For example, General Electric's Geniuslink enables organizations to implement techenabled and crowd-powered work models by providing them with experts when needed, thereby implementing project-based organizing (Biesenthal and Wilden, 2014). Related, the responsibility for careers has shifted from organizations to workers, leading to a more individualized career orientation (Gubler et al., 2014b). The concept of boundaryless careers stresses individual's careers as being independent of traditional organizational career structures (Arthur and Rousseau, 2001), given that employees move across organizational boundaries of 
separate employers; seek and find validation and marketability from outside markets; and break away from existing ways of hierarchy and career advancement (Gubler et al., 2014a).

The changing nature of industries towards the importance of ecosystems and platforms also affects the nature of psychological contracts between organizations and employees. Much of previous research on psychological contracts has largely focused on the individual employee level of analysis (Baruch and Rousseau, 2018). For example, Baruch and Rousseau (2018, p. 3) stress the importance to "assess employment-related exchange arrangements beyond the individual worker and an employer, where participants (workers, managers, employers, clients, team members, network partners, etc.) develop multi-faceted psychological contracts across several stakeholders", which also operate across different organizational levels. In platform organizations such as Uber, $M \& S$ 's concepts of inducement-motivation, satisfaction, and search can be adapted to be given a "second youth."

Finally, we showed that in time periods 2 and 3 upper echelon research drew on $M \& S$. Related, and building on $M \& S$, the micro-foundations research stream in strategy has provided us with valuable insights into senior managers and their decision-making, including dynamic managerial capabilities with their focus on cognition (Adner and Helfat, 2003; Helfat and Martin, 2015). However, less research has looked at the role of middle managers in organizations, although these employees play an important role in implementing strategies (Balogun and Johnson, 2005; Wooldridge et al., 2008). Notable exceptions are studies by Glast et al. (2016) and Heyden et al. (2018) who show that lower-level managers initiate and implement change. This is due to these managers more directly being closer to technological and market developments (Fourné et al., 2014). Thus, we suggest that future research should investigate these managers' decision-making processes, their motivations, and how organizations 
can best design incentives that align with these motivations, as well as how they design their decisions to exit the organization and pursue future opportunities.

\section{Innovation and change}

Related to Makadok et al.'s (2018) lever 6 of advancing theory ('When'), we believe that $M \& S$ 's assumptions need to be more critically applied to the today's context of innovation and change. Linked to the idea of co-creation, today's business environments have also led to core business processes, such as innovation, being distributed across the ecosystem, thereby indicating a need for permeable firm boundaries (Randhawa et al., 2016). Our data have shown that current research citing $M \& S$ is skewed toward innovation-related topics. Innovation-related research identifies the inability of organizations to organize, control, and conduct all the value chain activities necessary to achieve innovation success in-house as one of the core 'problems' facing firms today. For example, research on open innovation proposes that in order to drive innovation-related activities, organizational boundaries should open up moving to a relational system with external partners (Bogers and West, 2012; Chesbrough, 2006). Consequently, research has looked at innovation as the result of intentional and planned inflows and outflows of knowledge between partners (Chesbrough, 2003; Enkel et al., 2009). This research stream is yet to resolve questions around optimal organizational structures to motivate and incentivize employees to share and absorp innovation across organizational boundaries (Randhawa et al., 2019), for which it could draw on some of $M \& S$ 's key ideas.

Picking up on the above point of looking at multi-level phenomena, future research could build on $M \& S$ to better reflect the complexity of the role of the individual in open innovation and strategy perspectives. Even though these concepts are situated at the organizational level, organizations rely deeply on individual actions; for example, firms deploy crowdsourcing by 
engaging an external voluntary crowd of individuals to gather innovative ideas and solutions (Afuah and Tucci, 2012; Boudreau and Lakhani, 2009; Howe, 2006). Only limited research has investigated the relationships between organizations and open innovation communities and platforms (Dahlander and Wallin, 2006). More specifically, previous research has been critical of the fact that little research has investigated the individual's role and personal motivations in open inovation related activities (Randhawa et al., 2016).

An open system of innovation necessarily requires a change in behavior at the individual level fostered and coordinated by organizational structure, routines, and activities. In $M \& S$, internal employees are assumed to conduct all innovation-related processes, and thus need to be incentivized accordingly. However, nowadays organizations complement or even substitute internal employees with external crowds to drive innovation. In this context, Lifshitz-Assaf (2018), investigating NASA, found that engaging in open innovation can only lead to breakthrough innovation when R\&D employees adjust their own professional identity. That is, only when employees are able to truly adopt external knowledge and share internal knowledge through refocusing their identity, external solutions will be incorporated. On the other hand, when $R \& D$ employees try to implement open innovation without changing their own identity, R\&D processes will not change. Related, Randhawa et al. (2019) find that organizational open innovation success depends on the degree of project team motivation to implement crowdsourcing. More specifically, motivated employees feel a sense of 'reciprocal responsibility' (Hamel and Prahalad, 1989), inspires “organizational members to higher levels of achievement" (Hart, 1992, p. 337), in turn leading to better engagement in open innovation and positive innovation outcomes. Thus, future research is needed to extend the discussions about motivation and incentives to both external crowds as employee substitutes as well as how 
employees can be motivated to engage with external stakeholders to foster innovation and accept external ideas. While the basic idea of $M \& S$ 's inducement-motivation can be applied to this context, the intricacies of this relationship are significantly more complex.

\section{CONCLUSION}

In this paper, (1) we provided an empirically grounded summary of $M \& S ;(2)$ we empirically explicated the impact of $M \& S$ over time and discussed the influence of $M \& S$ on current research; and (3) we envisioned suggestions for future research. Despite the validity and strengths of the multi-methodological approach we have used, there are limitations to our study. Some are procedural. For example, we opted to exclude books, book chapters, and conference proceedings, thereby limiting ourselves to work that the review process may have forced to conform more to traditional perspectives. This is noteworthy as, particularly during the initial periods of our analysis, books had a more prominent stance in the business field than in later periods. By looking at specific time periods, we also may have lost sight of when critical changes in thinking occurred and erroneously report more stability than was present. Due to the large number of articles included in this study, we conducted the text mining on the abstracts of articles only. Although this is in line with previous research (Huber et al., 2014), future research could identify relevant subsamples of interest, and then run the presented analyses on the full text of the articles. We have attempted to address many of these issues in an Online Appendix.

Our results reveal that $M \& S$ has had significant influence on academic scholarship, with this effect having arisen in an evolutionary fashion. Scholars have integrated their ideas, concepts, themes and structures to facilitate and enhance their own work across a variety of fields. What is most remarkable is not that this tendency existed but that it appears to be accelerating as more and more scholars are looking to $M \& S$ for ideas an inspiration (see Table 
II). Indeed, what makes $M \& S$ influence so long lasting is the fact that each generation of scholars and each disciplinary variety of scholars still find new and helpful insights when reading the book from their own perspective. Indeed, to echo our introductory quote, $M \& S$ represents a classic in the sense that it has never exhausted all it has to say to its readers with more and more readers seeming to look to it for inspiration. 


\section{NOTES}

Figure 1: Concept and Theme map based on text mining of March and Simon (1958)

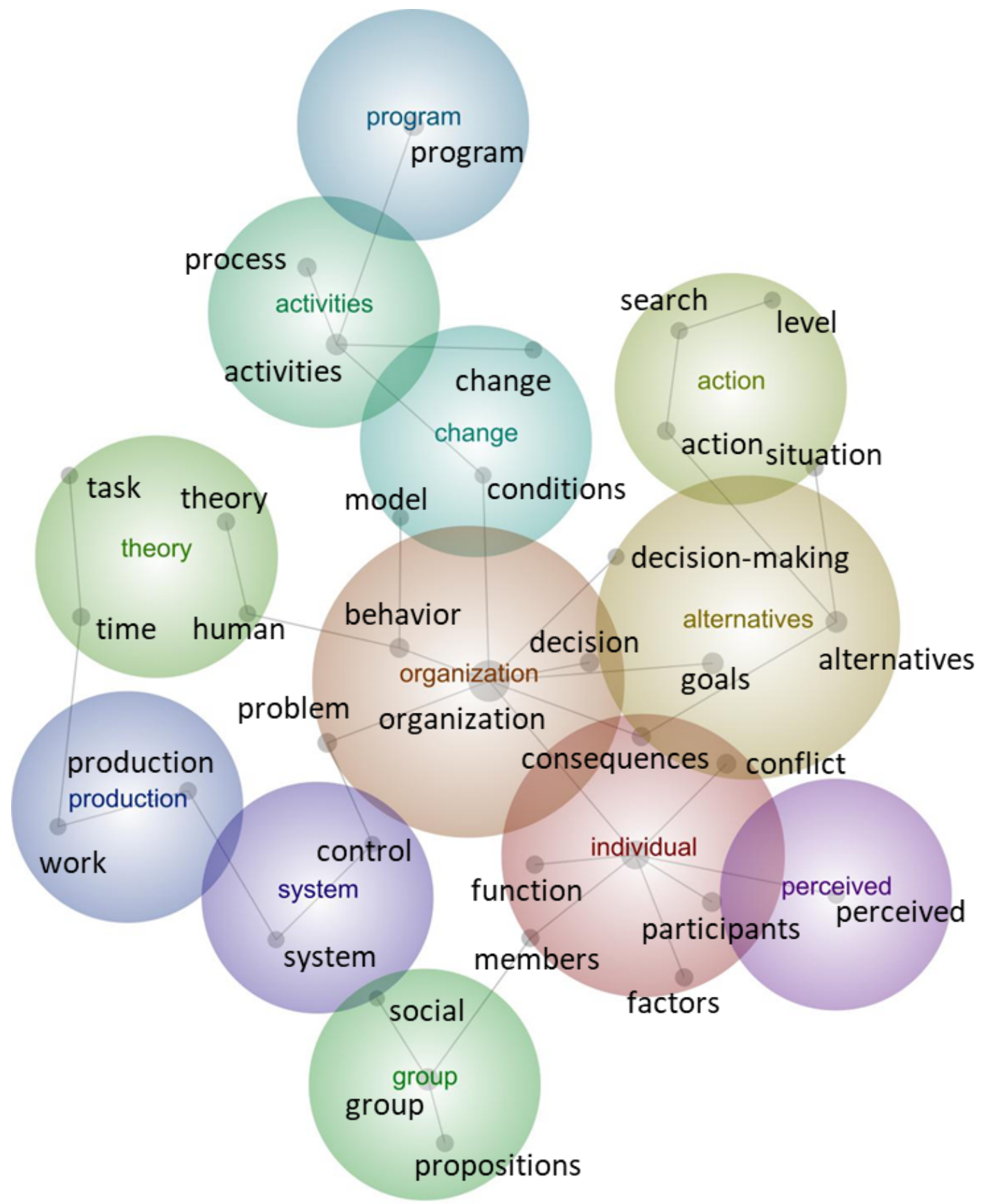


ure 3a and b: Coupling and text mining period 1973-1987
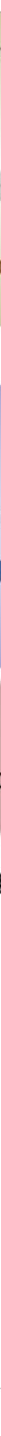

Cluster 22 
ure 4a and b: Coupling and text mining period 1988-2002
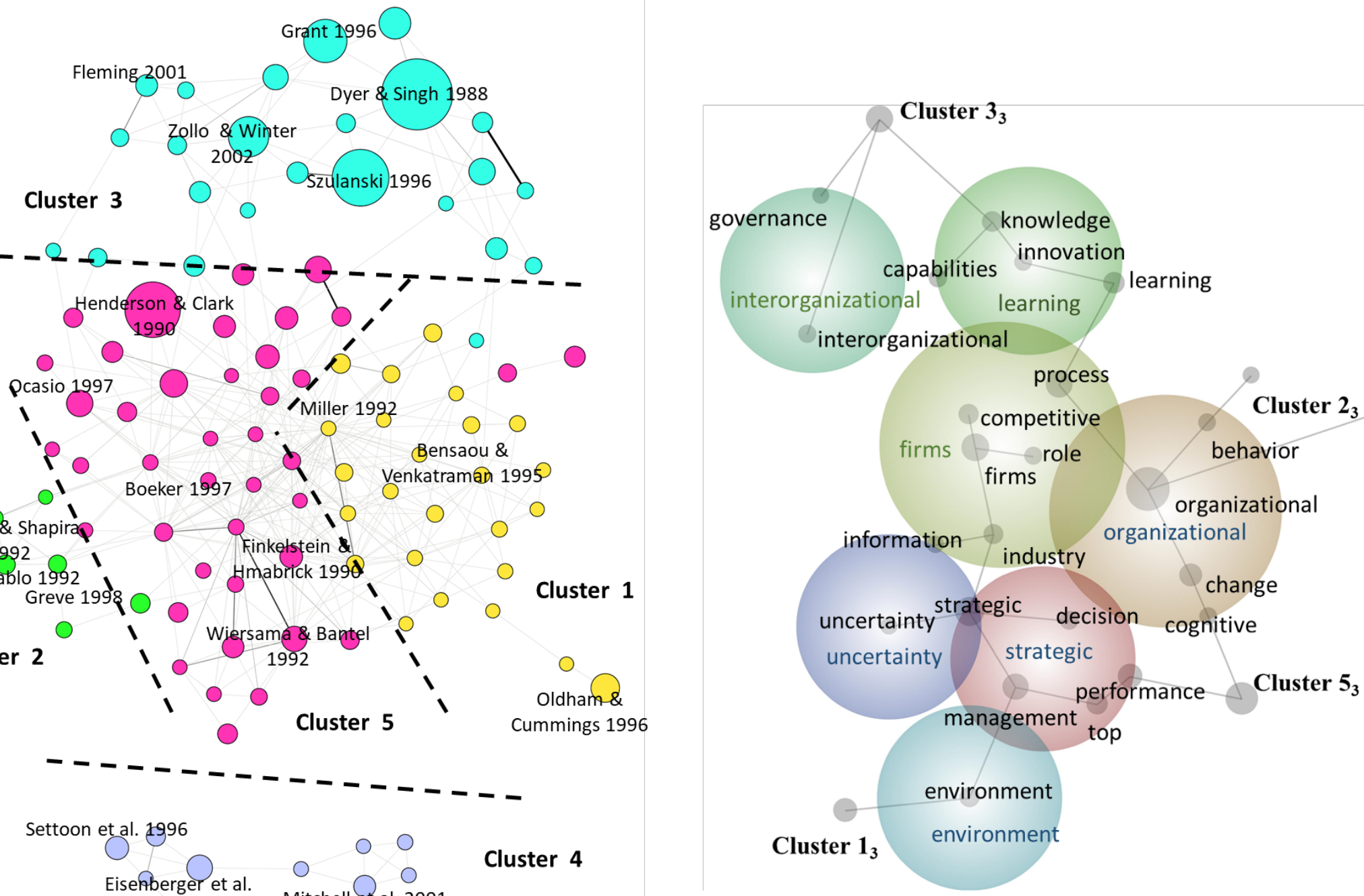
Table I: Themes and concepts by chapters

\begin{tabular}{|c|c|c|c|c|c|c|c|c|c|}
\hline \multicolumn{5}{|c|}{ Entire book } & \multicolumn{5}{|c|}{ Chapter 2} \\
\hline Theme & Con. & Concept & Count & Relev. & Theme & Con. & Concept & Count & Relev. \\
\hline \multirow{7}{*}{ individual } & $100 \%$ & individual & 386 & $45 \%$ & organization & $100 \%$ & organization & 63 & $95 \%$ \\
\hline & & participants & 162 & $19 \%$ & & & tasks & 51 & $77 \%$ \\
\hline & & conflict & 160 & $19 \%$ & & & process & 26 & $39 \%$ \\
\hline & & factors & 143 & $17 \%$ & & & purpose & 17 & $26 \%$ \\
\hline & & consequences & 126 & $15 \%$ & theory & $70 \%$ & theory & 41 & $62 \%$ \\
\hline & & function & 117 & $14 \%$ & & & problem & 40 & $61 \%$ \\
\hline & & members & 106 & $12 \%$ & & & departmentalization & 21 & $32 \%$ \\
\hline \multirow[t]{4}{*}{ organization } & $98 \%$ & organization & 855 & $100 \%$ & & & formal & 17 & $26 \%$ \\
\hline & & problem & 169 & $20 \%$ & activities & $62 \%$ & activities & 66 & $100 \%$ \\
\hline & & behavior & 159 & $19 \%$ & & & group & 20 & $30 \%$ \\
\hline & & decision & 136 & $16 \%$ & & & efficient & 17 & $26 \%$ \\
\hline \multirow[t]{5}{*}{ alternatives } & $42 \%$ & goals & 227 & $27 \%$ & & & fatigue & 12 & $18 \%$ \\
\hline & & alternatives & 219 & $26 \%$ & time & $55 \%$ & time & 53 & $80 \%$ \\
\hline & & conflict & 160 & $19 \%$ & & & work & 42 & $64 \%$ \\
\hline & & consequences & 126 & $15 \%$ & & & standard & 15 & $23 \%$ \\
\hline & & decision-making & 81 & $9 \%$ & production & $51 \%$ & human & 25 & $38 \%$ \\
\hline \multirow{4}{*}{ action } & $35 \%$ & situation & 136 & $16 \%$ & & & machine & 19 & $29 \%$ \\
\hline & & level & 126 & $15 \%$ & & & production & 17 & $26 \%$ \\
\hline & & action & 120 & $14 \%$ & & & methods & 9 & $14 \%$ \\
\hline & & search & 105 & $12 \%$ & propositions & $34 \%$ & propositions & 20 & $30 \%$ \\
\hline \multirow[t]{4}{*}{ theory } & $35 \%$ & theory & 158 & $18 \%$ & & & form & 12 & $18 \%$ \\
\hline & & time & 143 & $17 \%$ & & & empirical & 12 & $18 \%$ \\
\hline & & task & 118 & $14 \%$ & & & coordination & 10 & $15 \%$ \\
\hline & & human & 90 & $11 \%$ & management & $18 \%$ & behavior & 15 & $23 \%$ \\
\hline \multirow[t]{3}{*}{ group } & $33 \%$ & group & 268 & $31 \%$ & & & management & 14 & $21 \%$ \\
\hline & & propositions & 165 & $19 \%$ & worker & $4 \%$ & worker & 15 & $23 \%$ \\
\hline & & social & 62 & $7 \%$ & Chapte & & & & \\
\hline \multirow[t]{2}{*}{ activities } & $29 \%$ & activities & 236 & $28 \%$ & Theme & Con. & Concept & Count & Relev. \\
\hline & & process & 188 & $22 \%$ & organization & $100 \%$ & organization & 185 & $100 \%$ \\
\hline \multirow[t]{3}{*}{ change } & $22 \%$ & change & 114 & $13 \%$ & & & goals & 53 & $29 \%$ \\
\hline & & model & 92 & $11 \%$ & & & participation & 44 & $24 \%$ \\
\hline & & conditions & 91 & $11 \%$ & consequences & $85 \%$ & consequences & 63 & $34 \%$ \\
\hline program & $16 \%$ & program & 278 & $33 \%$ & & & behavior & 49 & $26 \%$ \\
\hline \multirow[t]{2}{*}{ production } & $16 \%$ & production & 124 & $15 \%$ & & & system & 48 & $26 \%$ \\
\hline & & work & 117 & $14 \%$ & & & model & 47 & $25 \%$ \\
\hline system & $13 \%$ & system & 106 & $12 \%$ & & & human & 16 & $9 \%$ \\
\hline & & control & 65 & $8 \%$ & individual & $85 \%$ & individual & 132 & $71 \%$ \\
\hline & & social & 62 & $7 \%$ & & & work & 30 & $16 \%$ \\
\hline perceived & $9 \%$ & perceived & 110 & $13 \%$ & & & satisfaction & 23 & $12 \%$ \\
\hline Chapt & & & & & & & needs & 21 & $11 \%$ \\
\hline Theme & Con. & Concept & Count & Relev. & group & $61 \%$ & group & 155 & $84 \%$ \\
\hline organizations & $100 \%$ & organizations & 81 & $100 \%$ & & & factors & 54 & $29 \%$ \\
\hline & & behavior & 24 & $30 \%$ & relations & $57 \%$ & relations & 58 & $31 \%$ \\
\hline & & human & 13 & $16 \%$ & & & productivity & 52 & $28 \%$ \\
\hline & & influence & 12 & $15 \%$ & & & perceived & 39 & $21 \%$ \\
\hline & & social & 10 & $12 \%$ & identification & $37 \%$ & identification & 69 & $37 \%$ \\
\hline & & environment & 10 & $12 \%$ & & & norms & 29 & $16 \%$ \\
\hline & & significant & 8 & $10 \%$ & & & task & 26 & $14 \%$ \\
\hline & & system & 7 & $9 \%$ & control & $35 \%$ & control & 38 & $21 \%$ \\
\hline & & formal & 7 & $9 \%$ & & & decisions & 32 & $17 \%$ \\
\hline & & psychologists & 4 & $5 \%$ & & & hierarchy & 20 & $11 \%$ \\
\hline & & society & 4 & $5 \%$ & alternatives & $34 \%$ & alternatives & 54 & $29 \%$ \\
\hline & & individual & 3 & $4 \%$ & & & evoked & 43 & $23 \%$ \\
\hline propositions & $13 \%$ & propositions & 25 & $31 \%$ & members & $20 \%$ & members & 47 & $25 \%$ \\
\hline & & members & 4 & $5 \%$ & time & $5 \%$ & time & 16 & $9 \%$ \\
\hline time & $10 \%$ & time & 15 & $19 \%$ & & & & & \\
\hline & & memory & 8 & $10 \%$ & & & & & \\
\hline specificity & $5 \%$ & specificity & 7 & $9 \%$ & & & & & \\
\hline & & degree & 6 & $7 \%$ & & & & & \\
\hline evoked & $5 \%$ & evoked & 10 & $12 \%$ & & & & & \\
\hline & & process & 6 & $7 \%$ & & & & & \\
\hline variable & $5 \%$ & variable & 19 & $23 \%$ & & & & & \\
\hline theory & $4 \%$ & theory & 12 & $15 \%$ & & & & & \\
\hline aspects & $3 \%$ & aspects & 7 & $9 \%$ & & & & & \\
\hline action & $2 \%$ & action & 10 & $12 \%$ & & & & & \\
\hline
\end{tabular}




\begin{tabular}{|c|c|c|c|c|c|c|c|c|c|}
\hline \multicolumn{5}{|l|}{ Chapter 4} & \multicolumn{3}{|c|}{ Chapter 6 } & \multirow[b]{2}{*}{ Count } & \multirow[b]{2}{*}{ Relev. } \\
\hline Theme & Con. & Concept & Count & Relev. & Theme & Con. & Concept & & \\
\hline \multirow{6}{*}{ perceived } & $100 \%$ & perceived & 50 & $34 \%$ & organization & $100 \%$ & 6 organization & 139 & $94 \%$ \\
\hline & & alternatives & 50 & $34 \%$ & & & individual & 36 & $24 \%$ \\
\hline & & movement & 44 & $30 \%$ & & & tasks & 23 & $16 \%$ \\
\hline & & factors & 36 & $25 \%$ & & & problem & 22 & $15 \%$ \\
\hline & & search & 24 & $17 \%$ & & & complex & 18 & $12 \%$ \\
\hline & & satisfaction & 19 & $13 \%$ & program & $75 \%$ & program & 148 & $100 \%$ \\
\hline \multirow[t]{3}{*}{ organization } & $82 \%$ & organization & 145 & $100 \%$ & & & performance & 29 & $20 \%$ \\
\hline & & participants & 86 & $59 \%$ & & & stimulus & 15 & $10 \%$ \\
\hline & & behavior & 23 & $16 \%$ & situation & $70 \%$ & process & 56 & $38 \%$ \\
\hline \multirow[t]{3}{*}{ individual } & $53 \%$ & individual & 74 & $51 \%$ & & & situation & 52 & $35 \%$ \\
\hline & & change & 33 & $23 \%$ & & & definition & 22 & $15 \%$ \\
\hline & & groups & 30 & $21 \%$ & & & problem-solving & 15 & $10 \%$ \\
\hline \multirow[t]{4}{*}{ inducements } & $52 \%$ & inducements & 50 & $34 \%$ & alternatives & $53 \%$ & goals & 37 & $25 \%$ \\
\hline & & utility & 34 & $23 \%$ & & & alternatives & 35 & $24 \%$ \\
\hline & & balance & 21 & $14 \%$ & & & consequences & 25 & $17 \%$ \\
\hline & & inducements-contrib. & 13 & $9 \%$ & & & uncertainty & 13 & $9 \%$ \\
\hline \multirow[t]{4}{*}{ job } & $40 \%$ & job & 52 & $36 \%$ & activities & $37 \%$ & activities & 52 & $35 \%$ \\
\hline & & satisfaction & 19 & $13 \%$ & & & function & 20 & $14 \%$ \\
\hline & & workers & 18 & $12 \%$ & action & $31 \%$ & action & 39 & $26 \%$ \\
\hline & & conditions & 17 & $12 \%$ & & & decision & 25 & $17 \%$ \\
\hline employee & $17 \%$ & employee & 53 & $37 \%$ & rational & $30 \%$ & rational & 45 & $30 \%$ \\
\hline \multirow[t]{2}{*}{ level } & $11 \%$ & turnover & 32 & $22 \%$ & & & choice & 21 & $14 \%$ \\
\hline & & level & 24 & $17 \%$ & behavior & $22 \%$ & behavior & 26 & $18 \%$ \\
\hline work & $5 \%$ & work & 24 & $17 \%$ & & & structure & 19 & $13 \%$ \\
\hline business & $3 \%$ & business & 16 & $11 \%$ & communication & $17 \%$ & communication & 54 & $36 \%$ \\
\hline \multicolumn{3}{|l|}{ Chapter 5} & & & coordination & $9 \%$ & coordination & 22 & $15 \%$ \\
\hline \multirow{7}{*}{$\begin{array}{l}\text { Theme } \\
\text { organization }\end{array}$} & Con. & Concept & Count & Relev. & information & $9 \%$ & information & 24 & $16 \%$ \\
\hline & $100 \%$ & organization & 140 & $100 \%$ & Chapter & & & & \\
\hline & & conflict & 133 & $95 \%$ & Theme & Con. & Concept & Count & Relev. \\
\hline & & individual & 83 & $59 \%$ & organization & $100 \%$ & organization & 123 & $100 \%$ \\
\hline & & problems & 26 & $19 \%$ & & & program & 109 & $89 \%$ \\
\hline & & decision & 26 & $19 \%$ & & & innovation & 72 & $59 \%$ \\
\hline & & participants & 23 & $16 \%$ & & & activity & 60 & $49 \%$ \\
\hline goals & $22 \%$ & organization & 140 & $100 \%$ & & & level & 52 & $42 \%$ \\
\hline & & goals & 43 & $31 \%$ & & & change & 45 & $37 \%$ \\
\hline & & factors & 15 & $11 \%$ & & & units & 32 & $26 \%$ \\
\hline & & differentiation & 13 & $9 \%$ & & & criteria & 23 & $19 \%$ \\
\hline & & reward & 9 & $6 \%$ & process & $41 \%$ & process & 72 & $59 \%$ \\
\hline pressure & $16 \%$ & pressure & 21 & $15 \%$ & & & problem & 49 & $40 \%$ \\
\hline & & time & 14 & $10 \%$ & & & individual & 42 & $34 \%$ \\
\hline & & behavior & 14 & $10 \%$ & & & search & 27 & $22 \%$ \\
\hline & & information & 10 & $7 \%$ & & & time & 20 & $16 \%$ \\
\hline alternatives & $15 \%$ & alternatives & 55 & $39 \%$ & & & analysis & 18 & $15 \%$ \\
\hline & & search & 17 & $12 \%$ & action & $32 \%$ & 6 action & 42 & $34 \%$ \\
\hline decision-making & $13 \%$ & decision-making & 35 & $25 \%$ & & & structure & 27 & $22 \%$ \\
\hline & & members & 12 & $9 \%$ & & & theory & 26 & $21 \%$ \\
\hline bargaining & $9 \%$ & bargaining & 31 & $22 \%$ & & & attention & 24 & $20 \%$ \\
\hline & & game & 13 & $9 \%$ & & & choice & 18 & $15 \%$ \\
\hline situation & $6 \%$ & situation & 24 & $17 \%$ & price & $30 \%$ & planning & 60 & $49 \%$ \\
\hline theory & $4 \%$ & theory & 21 & $15 \%$ & & & price & 48 & $39 \%$ \\
\hline & & & & & & & mechanism & 34 & $28 \%$ \\
\hline & & & & & & & conditions & 27 & $22 \%$ \\
\hline & & & & & & & decision-making & 24 & $20 \%$ \\
\hline & & & & & goals & $27 \%$ & goals & 68 & $55 \%$ \\
\hline & & & & & & & operational & 35 & $28 \%$ \\
\hline & & & & & & & function & 19 & $15 \%$ \\
\hline & & & & & decision & $22 \%$ & planning & 60 & $49 \%$ \\
\hline & & & & & & & decision & 33 & $27 \%$ \\
\hline & & & & & & & conditions & 27 & $22 \%$ \\
\hline & & & & & & & decision-making & 24 & $20 \%$ \\
\hline & & & & & & & human & 17 & $14 \%$ \\
\hline & & & & & group & $9 \%$ & group & 37 & $30 \%$ \\
\hline & & & & & & & problem-solving & 21 & $17 \%$ \\
\hline
\end{tabular}

Connectivity (Con.): indicates the importance of the respective theme relative to the most central theme

Relevance (Relev.): indicates the importance of the respective concept relative to the most central concept 
Table II: Areas citing March and Simon (1958) by academic field and time period

\begin{tabular}{|c|c|c|c|c|c|c|c|c|c|c|}
\hline \multirow[t]{2}{*}{ Area } & \multicolumn{2}{|c|}{$\begin{array}{l}\text { Period 1-4: } \\
1958 \text { - 2017 }\end{array}$} & \multicolumn{2}{|c|}{$\begin{array}{c}\text { Period 1: } \\
1958-1972\end{array}$} & \multicolumn{2}{|c|}{$\begin{array}{c}\text { Period 2: } \\
\text { 1973 - } 1987\end{array}$} & \multicolumn{2}{|c|}{$\begin{array}{c}\text { Period 3: } \\
1988-2002\end{array}$} & \multicolumn{2}{|c|}{$\begin{array}{c}\text { Period 4: } \\
2003-2017\end{array}$} \\
\hline & $n$ & $\%$ & $n$ & $\%$ & $n$ & $\%$ & $n$ & $\%$ & $n$ & $\%$ \\
\hline \multicolumn{11}{|c|}{ Panel A: Across scientific fields } \\
\hline Business \& Economics & 3389 & $46 \%$ & 183 & $38 \%$ & 667 & $38 \%$ & 928 & $45 \%$ & 1611 & $52 \%$ \\
\hline Psychology & 784 & $11 \%$ & 57 & $12 \%$ & 192 & $11 \%$ & 237 & $12 \%$ & 298 & $10 \%$ \\
\hline Social Sci. & 394 & $5 \%$ & 38 & $8 \%$ & 143 & $8 \%$ & 101 & $5 \%$ & 112 & $4 \%$ \\
\hline Public Administration & 367 & $5 \%$ & 14 & $3 \%$ & 96 & $5 \%$ & 93 & $5 \%$ & 164 & $5 \%$ \\
\hline Sociology & 319 & $4 \%$ & 48 & $10 \%$ & 110 & $6 \%$ & 97 & $5 \%$ & 64 & $2 \%$ \\
\hline Government \& Law & 266 & $4 \%$ & 24 & $5 \%$ & 113 & $6 \%$ & 61 & $3 \%$ & 68 & $2 \%$ \\
\hline Computer Sci. & 248 & $3 \%$ & 5 & $1 \%$ & 44 & $3 \%$ & 69 & $3 \%$ & 130 & $4 \%$ \\
\hline Operations \& Mgmt. & & & & & & & & & & \\
\hline Sci. & 246 & $3 \%$ & 14 & $3 \%$ & 50 & $3 \%$ & 81 & $4 \%$ & 101 & $3 \%$ \\
\hline Engineering & 219 & $3 \%$ & 8 & $2 \%$ & 38 & $2 \%$ & 73 & $4 \%$ & 100 & $3 \%$ \\
\hline Inform. \& Library Sci. & 184 & $2 \%$ & 8 & $2 \%$ & 19 & $1 \%$ & 38 & $2 \%$ & 119 & $4 \%$ \\
\hline Education & 182 & $2 \%$ & 21 & $4 \%$ & & & 52 & $3 \%$ & 48 & $2 \%$ \\
\hline International Relations & 59 & $1 \%$ & 9 & $2 \%$ & 29 & $2 \%$ & & & & \\
\hline Urban Studies & & & 6 & $1 \%$ & 61 & $3 \%$ & & & & \\
\hline \multicolumn{11}{|c|}{ Panel B: Within Business \& Economics } \\
\hline Gen. Mgmt. \& Strategy & 1174 & $35 \%$ & 76 & $42 \%$ & 276 & $41 \%$ & 326 & $35 \%$ & 496 & $31 \%$ \\
\hline Org. Behavior \& HRM & 843 & $25 \%$ & 33 & $18 \%$ & 150 & $22 \%$ & 257 & $28 \%$ & 403 & $25 \%$ \\
\hline Economics & 262 & $8 \%$ & 23 & $13 \%$ & 44 & $7 \%$ & 73 & $8 \%$ & 122 & $8 \%$ \\
\hline Mgmt. Sci. \& & & & & & & & & & & \\
\hline Operations & 234 & $7 \%$ & 13 & $7 \%$ & 51 & $8 \%$ & 65 & $7 \%$ & 105 & $7 \%$ \\
\hline Marketing & 155 & $5 \%$ & 8 & $4 \%$ & 37 & $6 \%$ & 38 & $4 \%$ & 72 & $4 \%$ \\
\hline Other & 128 & $4 \%$ & 11 & $6 \%$ & 24 & $4 \%$ & 17 & $2 \%$ & 76 & $5 \%$ \\
\hline Innovation & 123 & $4 \%$ & & & 10 & $1 \%$ & 41 & $4 \%$ & 72 & $4 \%$ \\
\hline Psychology & 109 & $3 \%$ & 8 & $4 \%$ & 21 & $3 \%$ & 32 & $3 \%$ & 48 & $3 \%$ \\
\hline Int. Business & 102 & $3 \%$ & 3 & $2 \%$ & 15 & $2 \%$ & 15 & $2 \%$ & 69 & $4 \%$ \\
\hline MIS, KM & 89 & $3 \%$ & & & 6 & $1 \%$ & 21 & $2 \%$ & 62 & $4 \%$ \\
\hline Finance \& Accounting & 78 & $2 \%$ & 8 & $4 \%$ & 27 & $4 \%$ & 21 & $2 \%$ & 22 & $1 \%$ \\
\hline Entrepreneurship & 65 & $2 \%$ & & & & & 16 & $2 \%$ & 49 & $3 \%$ \\
\hline
\end{tabular}

Note: Only areas $>1 \%$ are included in this table 
le III: Clusters and central publications by time period

\begin{tabular}{|c|c|c|c|c|c|c|}
\hline \multicolumn{3}{|c|}{ Period 1: $1958-1972$} & \multicolumn{4}{|c|}{ Period 2: 1973 - 1987} \\
\hline Cit. Publication & Centr. & Publication & Cl. Cit. & Publication & Centr. & Publication \\
\hline 324 Hrebiniak \& Alutto 1972 & 0.83 & Hrebiniak \& Alutto 1972 & $0 \quad 2476$ & 6 Daft \& Lengel 1986 & 0.84 & Tushman 1979 \\
\hline 198 Hall et al. 1970 & 0.71 & Hall 1971 & $0 \quad 1575$ & 5 Daft \& Weick 1984 & 0.84 & Daft \& Macintosh 1981 \\
\hline 150 Hall 1971 & 0.71 & Hall et al. 1970 & 613 & 3 Milliken 1987 & 0.80 & Daft \& Lengel 1986 \\
\hline 818 Simon 1959 & 1.00 & Simon 1959 & 199219 & 9 Dimaggio \& Powell 1983 & 0.86 & Miller 1987 \\
\hline 13 Isard \& Dacey 1962 & 0.75 & Shubik 1961 & 12651 & 1 Hambrick \& Mason 1984 & 0.73 & Fredrickson 1986 \\
\hline 13 Dahl 1959 & 0.75 & Isard \& Dacey 1962 & 11148 & 8 Dess \& Beard 1984 & 0.73 & Hambrick \& Finkelstein 1987 \\
\hline 1024 Perrow 1967 & 0.56 & Perrow 1967 & 26090 & 0 Meyer \& Rowan 1977 & 0.81 & Cook 1977 \\
\hline 313 Collins 1971 & 0.50 & Hage \& Aiken 1969 & 332 & 2 Ouchi 1977 & 0.65 & Comstock \& Scott 1977 \\
\hline 270 Hage \& Aiken 1969 & 0.41 & Pugh et al. 1963 & 327 & 7 Cook 1977 & 0.65 & Hrebiniak 1974 \\
\hline 617 Hickson et al. 1971 & 0.89 & Hickson et al. 1971 & 32158 & 8 Mowday et al. 1979 & 0.76 & Steel \& Ovalle 1984 \\
\hline 385 Pondy 1967 & 0.67 & Walton \& Dutton 1969 & 31831 & 1 Eisenberger et al. 1986 & 0.76 & Farrell \& Rusbult 1981 \\
\hline 117 Walton \& Dutton 1969 & 0.67 & Pondy 1967 & 807 & 7 Mobley et al. 1979 & 0.72 & Mobley et al. 1979 \\
\hline 85 Katzell et al. 1961 & 0.75 & Parker 1963 & $4 \quad 1438$ & 8 Williamson 1981 & 0.52 & Kiesler \& Sproull 1982 \\
\hline 46 Indik 1963 & 0.75 & Katzell 1962 & 954 & 4 March \& Olsen 1984 & 0.51 & Schoemaker 1982 \\
\hline 26 Parker 1963 & 0.50 & Indik 1963 & 896 & 6 March \& Shapira 1987 & 0.47 & Williamson 1981 \\
\hline \multicolumn{3}{|c|}{ Period 3: 1988 - 2002} & \multicolumn{4}{|c|}{ Period 4: 2003 - 2017} \\
\hline Cit. Publication & Centr. & Publication & Cl. Cit. & Publication & Centr. & Publication \\
\hline 915 Oldham \& Cummings 1996 & 0.77 & Miller 1992 & 551 & 1 Jansen et al. 2006 & 0.73 & Agarwal et al. 2007 \\
\hline 409 Eisenhardt \& Zbaracki 1992 & 0.63 & Bensaou \& Venkatraman 1995 & 472 & 2 Jansen et al. 2005 & 0.71 & Phene et al. 2006 \\
\hline 333 Dean \& Bowen 1994 & 0.63 & Smith et al. 1991 & 440 & 0 Rosenkopf \& Almeida 2003 & 0.69 & Afuah \& Tucci 2012 \\
\hline 530 Sitkin \& Pablo 1992 & 0.75 & Greve 1998 & 792 & 2 Gibson \& Birkinshaw 2004 & 0.87 & Becker 2004 \\
\hline 419 Haunschild \& Miner 1997 & 0.67 & March \& Shapira 1992 & 582 & 2 Borgatti \& Cross 2003 & 0.87 & Lewin et al. 2011 \\
\hline 404 Bromiley 1991 & 0.67 & Bromiley 1991 & 291 & 1 Becker 2004 & 0.83 & Parmigiani \& Howard-G. 2011 \\
\hline 3243 Dyer \& Singh 1998 & 0.58 & Rosenkopf \& Nerkar 2001 & 374 & 4 Allen et al. 2003 & 0.60 & Griffeth et al. 2005 \\
\hline 2460 Szulanski 1996 & 0.53 & Zollo \& Winter 2002 & 294 & 4 Sun et al. 2007 & 0.57 & Lee et al. 2008 \\
\hline 1719 Grant 1996 & 0.52 & Dyer \& Singh 1998 & 211 & 1 Takeuchi et al. 2007 & 0.53 & Trevor \& Nyberg 2008 \\
\hline 751 Eisenberger et al. 1990 & 0.60 & Jaros et al. 1993 & 271 & 1 Gilbert 2005 & 0.86 & Gavetti et al. 2012 \\
\hline 620 Settoon et al. 1996 & 0.60 & Eisenberger et al. 1990 & 229 & 9 Ethiraj \& Levinthal 2004 & 0.80 & Gavetti 2012 \\
\hline 548 Mitchell et al. 2001 & 0.50 & $\begin{array}{l}\text { Mitchell et al. } 2001 \text { /Chen et al. } \\
1998\end{array}$ & 187 & 7 Gavetti et al. 2005 & 0.77 & Gavetti et al. 2007 \\
\hline 2392 Henderson \& Clark 1990 & 0.66 & Miller 1993 & 418 & 8 Mcevily et al. 2003 & 0.64 & Mcevily \& Marcus 2005 \\
\hline 856 Walsh \& Ungson 1991 & 0.66 & Lant et al. 1992 & 318 & 8 Moran 2005 & 0.61 & Villena et al. 2011 \\
\hline 799 Vandeven \& Poole 1995 & 0.63 & Boeker 1997 & 298 & 8 Mcevily \& Marcus 2005 & 0.58 & Lee 2007 \\
\hline
\end{tabular}




\section{le IV: Citation statistics for $M \& S$ in selected research areas}

\begin{tabular}{|c|c|c|c|c|c|c|c|}
\hline mple & \multicolumn{5}{|c|}{ New Organizational Forms } & \multicolumn{2}{|c|}{ Control Sample } \\
\hline & $\begin{array}{c}\text { Business } \\
\text { model } \\
\text { innovation }\end{array}$ & Ecosystems & Platforms & Block-chain & Industry 4.0 & $\begin{array}{c}\text { Industrial } \\
\text { organization }\end{array}$ & General mana: \\
\hline nal & $\begin{array}{l}\text { Business \& } \\
\text { management }\end{array}$ & $\begin{array}{l}\text { Business \& } \\
\text { management }\end{array}$ & $\begin{array}{l}\text { Business \& } \\
\text { management }\end{array}$ & $\begin{array}{l}\text { Business \& } \\
\text { management }\end{array}$ & $\begin{array}{l}\text { Business \& } \\
\text { management }\end{array}$ & $\begin{array}{l}\text { Business \& } \\
\text { management }\end{array}$ & $\begin{array}{l}\text { Business } \\
\text { manageme }\end{array}$ \\
\hline iction & none & none & none & none & none & none & last 10 yea \\
\hline $\begin{array}{l}\text { nal } \\
\text { iction }\end{array}$ & none & none & none & none & none & none & $\begin{array}{l}\text { High reputa } \\
\text { journals }\end{array}$ \\
\hline cations & 475 & $2,000^{\mathrm{B}}$ & $2,000^{\mathrm{B}}$ & 180 & 234 & 1,089 & $2,000^{\mathrm{B}}$ \\
\hline ences & & 108,656 & 102,656 & 6,096 & 9,028 & 42,119 & 191,079 \\
\hline $\begin{array}{l}\text { S ences } \\
\end{array}$ & 2 & 8 & 15 & 0 & 0 & 9 & 138 \\
\hline $\begin{array}{l}\text { S cit. } \\
\text { cles }\end{array}$ & $0.421 \%$ & $0.400 \%$ & $0.750 \%$ & $0.000 \%$ & $0.000 \%$ & $0.826 \%$ & $6.900 \%$ \\
\hline $\begin{array}{l}\text { S cit. } \\
\text { erences }\end{array}$ & $0.008 \%$ & $0.007 \%$ & $0.015 \%$ & $0.000 \%$ & $0.000 \%$ & $0.021 \%$ & $0.072 \%$ \\
\hline $\begin{array}{l}\text { st cited } \\
\text { ences }\end{array}$ & $\begin{array}{c}\text { Teece, } 2010 \\
\text { Zott et al. } \\
2011 \\
\text { Chesbrough, } \\
2010\end{array}$ & $\begin{array}{c}\text { Iansiti \& Levien, } \\
2004 \\
\text { Adner \& Kapoor, } \\
2010 \\
\text { Moore, } 1993\end{array}$ & $\begin{array}{c}\text { Chesbrough, } 2003 \\
\text { Barney, 1991 } \\
\text { Kaplan \& } \\
\text { Heanlein, } 2010\end{array}$ & $\begin{array}{c}\text { Nakamoto, } 2008 \\
\text { Swan, 2015 } \\
\text { Tapscott \& } \\
\text { Tapscott, } 2016\end{array}$ & $\begin{array}{c}\text { Brettel et al. } 2014 \\
\text { Kagermann et al. } \\
2013 \\
\text { Stock \& Seliger, } \\
2016\end{array}$ & $\begin{array}{c}\text { Porter, } 1980 \\
\text { Barney, } 1991 \\
\text { Porter, } 1985\end{array}$ & $\begin{array}{r}\text { Barney, } 19 \\
\text { Cyert \& March } \\
\text { March, } 19\end{array}$ \\
\hline
\end{tabular}

election of high reputation journals include: Academy of Management Journal, Academy of Management Review, Administrative Science Quarterly, Jou nagement, Journal of Management Studies, Organization Science, Strategic Management Journal.

imited to the 2,000 most cited publications. We removed the Eisenhardt (1989) publication from the general management and platform samples, as it is a thod article. 


\section{le V: Sample future research questions}

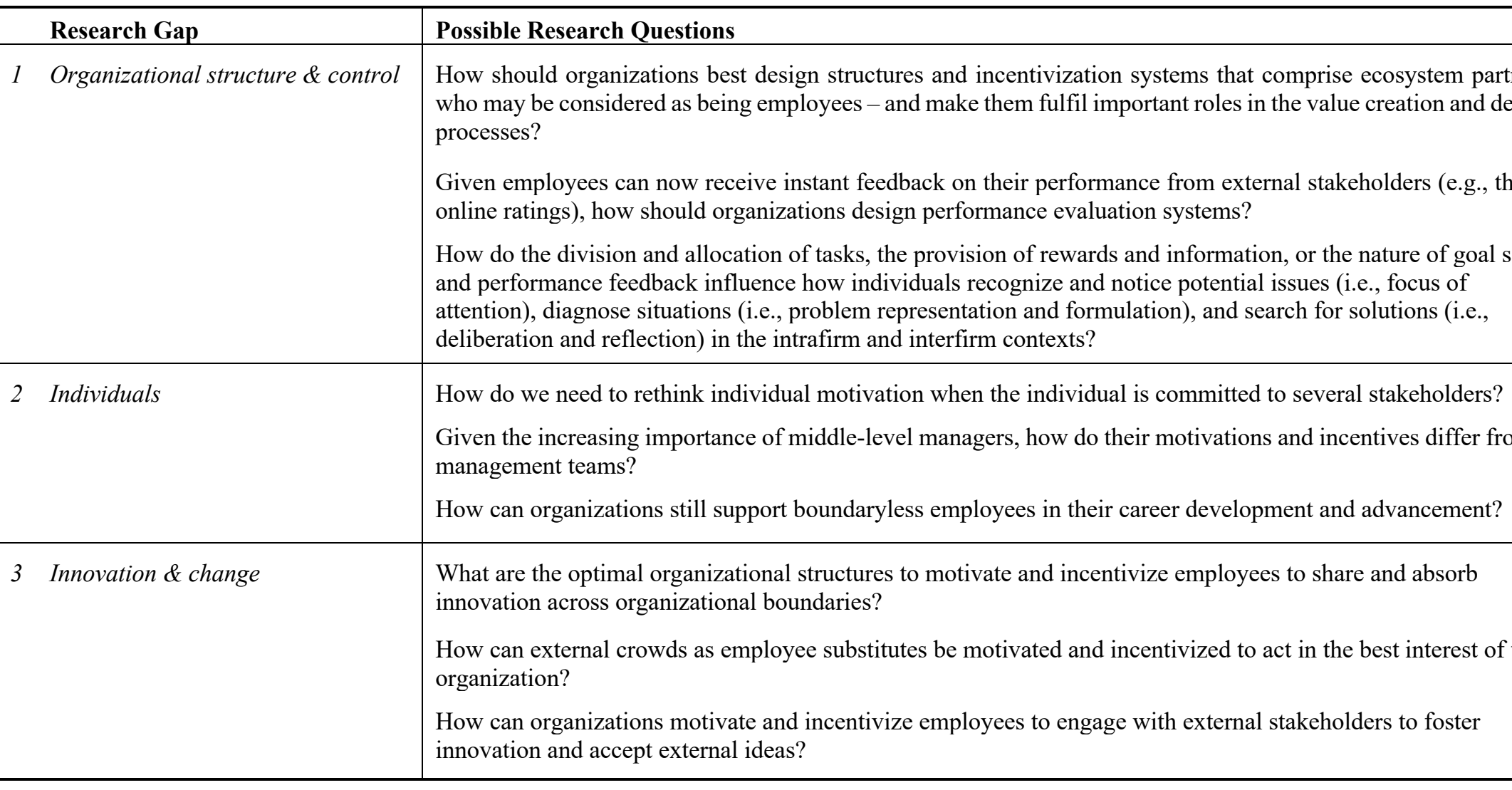




\section{References}

Adner, R. and Helfat, C. (2003). 'Corporate effects and dynamic managerial capabilities'. Strategic Management Journal, 24, 1011 - 25.

Afuah, A. and Tucci, C. L. (2012). 'Crowdsourcing as a solution to distant search'. Academy of Management Review, 37, 355-75.

Allen, D. G., Shore, L. M. and Griffeth, R. W. (2003). 'The role of perceived organizational support and supportive human resource practices in the turnover process'. Journal of Management, 29, 99-118.

Angle, H. L. and Perry, J. L. (1981). 'An empirical assessment of organizational commitment and organizational effectiveness'. Administrative Science Quarterly, 26, 1-14.

Argote, L. and Greve, H. R. (2007). 'A behavioral theory of the firm-40 years and counting: Introduction and impact'. Organization Science, 18, 337-49.

Arthur, M. B. and Rousseau, D. M. (2001). The boundaryless career: A new employment principle for a new organizational era. Oxford University Press on Demand.

Balogun, J. and Johnson, G. (2005). 'From intended strategies to unintended outcomes: The impact of change recipient sensemaking'. Organization Studies, 26, 1573-601.

Bardhi, F. and Eckhardt, G. M. (2012). 'Access-based consumption: The case of car sharing'. Journal of Consumer Research, 39, 881-98.

Barr, P. S., Stimpert, J. L. and Huff, A. S. (1992). 'Cognitive change, strategic action, and organizational renewal'. Strategic Management Journal, 13, 15-36.

Baruch, Y. and Rousseau, D. M. (2018). 'Integrating psychological contracts and ecosystems in career studies and management'. Academy of Management Annals, Forthcoming. 
Bateman, T. S. and Strasser, S. (1984). 'A longitudinal analysis of the antecedents of organizational commitment'. Academy of Management Journal, 27, 95-112.

Baum, J. A. and Dahlin, K. B. (2007). 'Aspiration performance and railroads' patterns of learning from train wrecks and crashes'. Organization Science, 18, 368-85.

Becker, M. C. (2004). 'Organizational routines: A review of the literature'. Industrial and Corporate Change, 13, 643-77.

Bedeian, A. G. and Wren, D. A. (2001). 'Most influential management books of the 20th century'. Organizational Dynamics, 29, 221-25.

Bensaou, M. and Venkatraman, N. (1995). 'Configurations of interorganizational relationships: A comparison between us and japanese automakers'. Management Science, 41, 1471-92.

Biesenthal, C. and Wilden, R. (2014). 'Multi-level project governance: Trends and opportunities'. International Journal of Project Management, 32, 1291-308.

Blondel, V. D., Guillaume, J.-L., Lambiotte, R. and Lefebvre, E. (2008). 'Fast unfolding of communities in large networks'. Journal of Statistical Mechanics: Theory and Experiment, 28.

Boeker, W. (1997). 'Strategic change: The influence of managerial characteristics and organizational growth'. Academy of Management Journal, 40, 152-70.

Bogers, M. and West, J. (2012). 'Managing distributed innovation: Strategic utilization of open and user innovation'. Creativity and Innovation Management, 21, 61-75.

Boudreau, K. and Lakhani, K. (2009). 'How to manage outside innovation'. MIT Sloan Management Review, 50, 69.

Boudreau, K. J. and Lakhani, K. R. (2013). 'Using the crowd as an innovation partner'. Harvard Business Review, 91, 60-69. 
Bromiley, P. (1991). 'Testing a causal model of corporate risk taking and performance'. Academy of Management Journal, 34, 37-59.

Burgelman, R. A. (1983). 'A process model of internal corporate venturing in the diversified major firm'. Administrative Science Quarterly, 223-44.

Calvino, I. (2014). Why read the classics? : Houghton Mifflin Harcourt.

Campbell, C., Pitt, L. F., Parent, M. and Berthon, P. R. (2011). 'Understanding consumer conversations around ads in a web 2.0 world'. Journal of Advertising, 40, 87-102.

Castrogiovanni, G. J. (1991). 'Environmental munificence: A theoretical assessment'. Academy of Management Review, 16, 542-65.

Chesbrough, H. (2003). 'The era of open innovation'. MIT Sloan Management Review, 44, 35 41.

Chesbrough, H. (2006). Open business models: How to thrive in the new innovation landscape. Boston: Harvard Business School Press.

Cirillo, B., Breschi, S. and Prencipe, A. (2018). 'Divide to connect: Reorganization through R\&D unit spinout as linking context of intra-corporate networks'. Research Policy, 47, 1585-600.

Cyert, R. M. and March, J. (1963). A behavioral theory of the firm. Englewood Cliffs, NJ: Prentice Hall.

Daft, R. L. and Lengel, R. H. (1986). 'Organizational information requirements, media richness and structural design'. Management Science, 32, 554-71.

Daft, R. L. and Weick, K. E. (1984). 'Toward a model of organizations as interpretation systems'. Academy of Management Review, 9, 284-95.

Dahlander, L. and Wallin, M. W. (2006). 'A man on the inside: Unlocking communities as complementary assets'. Research Policy, 35, 1243-59. 
Daniel, F., Lohrke, F. T., Fornaciari, C. J. and Turner, R. A. (2004). 'Slack resources and firm performance: A meta-analysis'. Journal of Business Research, 57, 565-74.

Dann, S. (2010). 'Redefining social marketing with contemporary commercial marketing definitions'. Journal of Business Research, 63, 147-53.

De Carolis, D. M. and Saparito, P. (2006). 'Social capital, cognition, and entrepreneurial opportunities: A theoretical framework'. Entrepreneurship Theory and Practice, 30, 41-56.

Denyer, D. and Tranfield, D. (2009). 'Producing a systematic review'. In D. Buchanan \& A. Bryman (Eds.), The sage handbook of organizational research methods. London: Sage Publications Ltd, 671-89.

Denyer, D., Tranfield, D. and Van Aken, J. E. (2008). 'Developing design propositions through research synthesis'. Organization Studies, 29, 393-413.

Devinney, T. M. and Hohberger, J. (2017). 'The past is prologue: Moving on from culture's consequences'. Journal of International Business Studies, 48, 48-62.

DiMaggio, P. and Powell, W. W. (1983). 'The iron cage revisited: Collective rationality and institutional isomorphism in organizational fields'. American Sociological Review, 48, 147-60.

Dosi, G. and Marengo, L. (2007). 'Perspective — on the evolutionary and behavioral theories of organizations: A tentative roadmap'. Organization Science, 18, 491-502.

Dyer, J. H. and Singh, H. (1998). 'The relational view: Cooperative strategy and sources of interorganizational competitive advantage'. Academy of Management Review, 23, 660-79.

Einsenberger, R., Cummings, J., Aemeli, S. and Lynch, P. (1997). 'Perceived organizational support, discretionary treatment, and job satisfaction'. Journal of Applied Psychology, 82, 812-20. 
Eisenberger, R., Huntington, R., Hutchison, S. and Sowa, D. (1986). 'Perceived organizational support'. Journal of Applied Psychology, 71, 500-07.

Eisenhardt, K. M. (1989). 'Building theories from case study research'. The Academy of Management Review, 14, 532-50.

Eisenhardt, K. M. and Graebner, M. E. (2007). 'Theory building from cases: Opportunities and challenges'. Academy of Management Journal, 50, 25-32.

Enkel, E., Gassmann, O. and Chesbrough, H. (2009). 'Open r\&d and open innovation: Exploring the phenomenon'. R and D Management, 39, 311-16.

Felps, W., Mitchell, T. R., Hekman, D. R., Lee, T. W., Holtom, B. C. and Harman, W. S. (2009). 'Turnover contagion: How coworkers' job embeddedness and job search behaviors influence quitting'. Academy of Management Journal, 52, 545-61.

Finkelstein, S. and Hambrick, D. C. (1990). 'Top-management-team tenure and organizational outcomes: The moderating role of managerial discretion'. Administrative Science Quarterly, 484-503.

Fleming, L. (2001). 'Recombinant uncertainty in technological search'. Management Science, 47, $117-32$.

Fleming, L. and Sorenson, O. (2001). 'Technology as a complex adaptive system: Evidence from patent data'. Research Policy, 30, 1019-39.

Fleming, L. and Sorenson, O. (2004). 'Science as a map in technological search'. Strategic Management Journal, 25, 909-28.

Fortunato, S. and Barthelemy, M. (2007). 'Resolution limit in community detection'. Proceedings of the National Academy of Sciences, 104, 36-41. 
Fourné, S. P., Jansen, J. J. and Mom, T. J. (2014). 'Strategic agility in mnes: Managing tensions to capture opportunities across emerging and established markets'. California Management Review, 56, 13-38.

Fredrickson, J. W. (1984). 'The comprehensiveness of strategic decision processes: Extension, observations, future directions'. Academy of Management Journal, 27, 445-66.

Gavetti, G., Greve, H. R., Levinthal, D. A. and Ocasio, W. (2012). 'The behavioral theory of the firm: Assessment and prospects'. Academy of Management Annals, 6, 1-40.

Gavetti, G. and Levinthal, D. (2000). 'Looking forward and looking backward: Cognitive and experiential search'. Administrative Science Quarterly, 45, 113-37.

Gavetti, G., Levinthal, D. and Ocasio, W. (2007). 'Neo-carnegie: The carnegie school's past, present, and reconstructing for the future'. Organization Science, 18, 523-36.

Ghoshal, S. and Bartlett, C. A. (1990). 'The multinational corporation as an interorganizational network'. Academy of Management Review, 15, 603-26.

Gilbert, C. G. (2006). 'Change in the presence of residual fit: Can competing frames coexist?'. Organization Science, 17, 150-67.

Glaser, L., Stam, W. and Takeuchi, R. (2016). 'Managing the risks of proactivity: A multilevel study of initiative and performance in the middle management context'. Academy of Management Journal, 59, 1339-60.

Govindarajan, V. (1988). 'A contingency approach to strategy implementation at the businessunit level: Integrating administrative mechanisms with strategy'. Academy of Management Journal, 31, 828-53. 
Grech, M. R., Horberry, T. and Smith, A. (2002). Human error in maritime operations: Analyses of accident reports using the leximancer tool. Paper presented at the Proceedings of the Human Factors and Ergonomics Society Annual Meeting.

Greve, H. R. (1998). 'Performance, aspirations, and risky organizational change'. Administrative Science Quarterly, 58-86.

Gubler, M., Arnold, J. and Coombs, C. (2014a). 'Organizational boundaries and beyond: A new look at the components of a boundaryless career orientation'. Career Development International, 19, 641-67.

Gubler, M., Arnold, J. and Coombs, C. (2014b). 'Reassessing the protean career concept: Empirical findings, conceptual components, and measurement'. Journal of Organizational Behavior, 35, S23-S40.

Hage, J. and Aiken, M. (1969). 'Routine technology, social structure, and organization goals'. Administrative Science Quarterly, 14, 366-76.

Hall, D. T., Schneider, B. and Nygren, H. T. (1970). 'Personal factors in organizational identification'. Administrative Science Quarterly, 15, 176-90.

Hambrick, D. C. and Mason, P. A. (1984). 'Upper echelons: The organization as a reflection of its top managers'. Academy of Management Review, 9, 193-206.

Hamel, G. and Prahalad, C. K. (1989). 'Strategic intent'. Harvard Business Review, May-June, 63-76.

Hammersley, M. (2001). 'On 'systematic' reviews of research literatures: A 'narrative' response to evans \& benefield'. British Educational Research Journal, 27, 543-54.

Harzing, A. (2018). Journal quality listVerfügbar unter: https://harzing.com/resources/journalquality-list [23/09/2018 
Helfat, C. and Martin, J. (2015). 'Dynamic managerial capabilities: Review and assessment of managerial impact on strategic change'. Journal of Management, 41, 1281-312.

Henderson, R. M. and Clark, K. B. (1990). 'Architectural innovation - the reconfiguration of existing product technologies and the failure of established firms'. Administrative Science Quarterly, 35, 9-30.

Heyden, M. L., Sidhu, J. S. and Volberda, H. W. (2018). 'The conjoint influence of top and middle management characteristics on management innovation'. Journal of Management, 44, $1505-29$.

Hickson, D. J. (1994). 'Book reviews : James march and herbert simon: Organizations, 2nd ed:1992, cambridge, ma, oxford: Blackwell. 287 pages'. Organization Studies, 15, 786-88.

Hickson, D. J., Hinings, C. R., Lee, C. A., Schneck, R. E. and Pennings, J. M. (1971). 'A strategic contingencies' theory of intraorganizational power'. Administrative Science Quarterly, 16, 216-29.

Hobday, M., Davies, A. and Prencipe, A. (2005). 'Systems integration: A core capability of the modern corporation'. Industrial and Corporate Change, 14, 1109-43.

Hofstede, G. (1983). 'The cultural relativity of organizational practices and theories'. Journal of International Business Studies, 14, 75-89.

Holtom, B. C. and O’Neill, B. S. (2004). 'Job embeddedness: A theoretical foundation for developing a comprehensive nurse retention plan'. Journal of Nursing Administration, 34, 216-27.

Howe, J. (2006). 'The rise of crowdsourcing'. Wired magazine, 14, 1-4.

Hrebiniak, L. G. and Alutto, J. A. (1972). 'Personal and role-related factors in the development of organizational commitment'. Administrative Science Quarterly, 17, 555-73. 
Huber, G. P. and McDaniel, R. R. (1986). 'The decision-making paradigm of organizational design'. Management Science, 32, 572-89.

Huber, J., Kamakura, W. and Mela, C. F. (2014). 'A topical history of jmr'. Journal of Marketing Research, 51, 84-91.

Huff, J. O., Huff, A. S. and Thomas, H. (1992). 'Strategic renewal and the interaction of cumulative stress and inertia'. Strategic Management Journal, 13, 55-75.

Ireland, R. D., Hitt, M. A., Bettis, R. A., Porras, D. and Auld, D. (1987). 'Strategy formulation processes: Differences in perceptions of strength and weaknesses indicators and environmental uncertainty by managerial level'. Strategic Management Journal, 8, 469-85.

Jacomy, M., Heymann, S., Venturini, T. and Bastian, M. (2011). 'Forceatlas2, a continuous graph layout algorithm for handy network visualization'. Medialab Center of Research.

Katzell, R. A., Barrett, R. S. and Parker, T. C. (1961). 'Job satisfaction, job performance, and situational characteristics'. Journal of Applied Psychology, 45, 65.

Kessler, M. M. (1963). 'Bibliographic coupling between scientific papers'. American Documentation, 14, 10-25.

Lambiotte, R., Delvenne, J.-C. and Barahona, M. (2008). 'Laplacian dynamics and multiscale modular structure in networks'. arXiv preprint arXiv:0812.1770.

Lant, T. K., Milliken, F. J. and Batra, B. (1992). 'The role of managerial learning and interpretation in strategic persistence and reorientation: An empirical exploration'. Strategic Management Journal, 13, 585-608.

Lewin, A. Y., Massini, S. and Peeters, C. (2011). 'Microfoundations of internal and external absorptive capacity routines'. Organization Science, 22, 81-98. 
Lifshitz-Assaf, H. (2018). 'Dismantling knowledge boundaries at nasa: The critical role of professional identity in open innovation'. Administrative Science Quarterly, 63, 746-82.

Lord, R. G. and Kernan, M. C. (1987). 'Scripts as determinants of purposeful behavior in organizations'. Academy of Management Review, 12, 265-77.

Lumineau, F. (2017). 'How contracts influence trust and distrust'. Journal of Management, 43, 1553-77.

Makadok, R., Burton, R. and Barney, J. (2018). 'A practical guide for making theory contributions in strategic management'. Strategic Management Journal, 39, 1530-45.

March, J. G. (1981). 'Footnotes to organizational change'. Administrative Science Quarterly, 26, $563-77$.

March, J. G. and Shapira, Z. (1987). 'Managerial perspectives on risk and risk taking'. Management Science, 33, 1404-18.

March, J. G. and Simon, H. A. (1958). 'Organizations'. New York: Wiley.

Martín-Martín, A., Orduna-Malea, E., Thelwall, M. and López-Cózar, E. D. (2018). 'Google scholar, web of science, and scopus: A systematic comparison of citations in 252 subject categories'. Journal of Informetrics, Forthcoming.

McEvily, B. and Marcus, A. (2005). 'Embedded ties and the acquisition of competitive capabilities'. Strategic Management Journal, 26, 1033-55.

McEvily, B., Perrone, V. and Zaheer, A. (2003). 'Trust as an organizing principle'. Organization Science, 14, 91-103.

Meyer, J. W. and Rowan, B. (1977). 'Institutionalized organizations: Formal structure as myth and ceremony'. American Journal of Sociology, 83, 340-63. 
Miller, D. (1987). 'Strategy making and structure: Analysis and implications for performance'. Academy of Management Journal, 30, 7-32.

Miller, D. (1992). 'Environmental fit versus internal fit'. Organization science, 3, 159-78.

Miller, D. (1993). 'The architecture of simplicity'. Academy of Management Review, 18, 116-38.

Miner, A. S., Amburgey, T. L. and Stearns, T. M. (1990). 'Interorganizational linkages and population dynamics: Buffering and transformational shields'. Administrative Science Quarterly, 689-713.

Mitchell, T. R., Holtom, B. C., Lee, T. W., Sablynski, C. J. and Erez, M. (2001). 'Why people stay: Using job embeddedness to predict voluntary turnover'. Academy of Management Journal, 44, 1102-21.

Mongeon, P. and Paul-Hus, A. (2016). 'The journal coverage of web of science and scopus: A comparative analysis'. Scientometrics, 106, 213-28.

Moore, J. F. (1996). The death of competition: Leadership and strategy in the age of business ecosystems. New York: Harper Business.

Moran, P. (2005). 'Structural vs. Relational embeddedness: Social capital and managerial performance'. Strategic Management Journal, 26, 1129-51.

Mowday, R. T., Steers, R. M. and Porter, L. W. (1979). 'The measurement of organizational commitment'. Journal of Vocational Behavior, 14, 224-47.

Nerkar, A. (2003). 'Old is gold? The value of temporal exploration in the creation of new knowledge'. Management Science, 49, 211-29.

Newman, M. E. (2004). 'Fast algorithm for detecting community structure in networks'. Physical Review E, 69, 066133. 
Parmigiani, A. and Howard-Grenville, J. (2011). 'Routines revisited: Exploring the capabilities and practice perspectives'. Academy of Management Annals, 5, 413-53.

Perrow, C. (1967). 'A framework for the comparative analysis of organizations'. American Sociological Review, 32, 194-208.

Persson, O., Danell, R. and Schneider, J. W. (2009). 'How to use bibexcel for various types of bibliometric analysis'. Celebrating scholarly communication studies: A Festschrift for Olle Persson at his 60th Birthday, 5, 9-24.

Pondy, L. R. (1967). 'Organizational conflict: Concepts and models'. Administrative Science Quarterly, 12, 296-320.

Powell, T. C., Lovallo, D. and Fox, C. R. (2011). 'Behavioral strategy'. Strategic Management Journal, 32, 1369-86.

Puranam, P., Alexy, O. and Reitzig, M. (2014). 'What's “new” about new forms of organizing?'. Academy of Management Review, 39, 162-80.

Ramos-Rodriguez, A. R. and Ruiz-Navarro, J. (2004). 'Changes in the intellectual structure of strategic management research: A bibliometric study of the strategic management journal, 1980-2000'. Strategic Management Journal, 25, 981-1004.

Randhawa, K., Wilden, R. and Hohberger, J. (2016). 'A bibliometric review of open innovation: Setting a research agenda'. Journal of Product Innovation Management, 33, 750-72.

Randhawa, K., Wilden, R. and West, J. (2019). 'Crowdsourcing without profit: The role of the seeker in open social innovation'. R\&d Management, 49, 298-317.

Rooney, D. (2005). 'Knowledge, economy, technology and society: The politics of discourse'. Telematics and Informatics, 22, 405-22. 
Rosenkopf, L. and Almeida, P. (2003). 'Overcoming local search through alliances and mobility'. Management Science, 49, 751-66.

Rosenkopf, L. and Nerkar, A. (2001). 'Beyond local search: Boundary-spanning, exploration and impact in the optical disc industry'. Strategic Management Journal, 22, 287-306.

Rousseau, D. M., Manning, J. and Denyer, D. (2008). '11 evidence in management and organizational science: Assembling the field's full weight of scientific knowledge through syntheses'. Academy of Management Annals, 2, 475-515.

Sako, M. and Chondrakis, G. (2017). 'Dynamic capabilities: Implications for firm boundaries and organizational design'. In D. J. Teece \& S. Leih (Eds.), The Oxford Handbook of Dynamic Capabilities: Oxford University Press.

Schmidt, S. M. and Kochan, T. A. (1972). 'Conflict: Toward conceptual clarity'. Administrative Science Quarterly, 17, 359-70.

Schuler, R. S. and Rogovsky, N. (1998). 'Understanding compensation practice variations across firms: The impact of national culture'. Journal of International Business Studies, 29, 159-77.

Settoon, R. P., Bennett, N. and Liden, R. C. (1996). 'Social exchange in organizations: Perceived organizational support, leader-member exchange, and employee reciprocity'. Journal of Applied Psychology, 81, 219.

Shrivastava, P. and Grant, J. H. (1985). 'Empirically derived models of strategic decision-making processes'. Strategic Management Journal, 6, 97-113.

Simon, H. A. (1947). Administrative behavior: A study of decision making processes in administrative organization. New York: Macmilian.

Simon, H. A. (1979). 'Rational decision making in business organizations'. The American Economic Review, 69, 493-513. 
Sitkin, S. B. and Pablo, A. L. (1992). 'Reconceptualizing the determinants of risk behavior'. Academy of Management Review, 17, 9-38.

Small, H. (1973). 'Co-citation in the scientific literature: A new measure of the relationship between two documents'. Journal of the American Society for Information Science, 24, 265 69.

Smith, A. E. (2003). Automatic extraction of semantic networks from text using leximancer. Paper presented at the Proceedings of the 2003 Conference of the North American Chapter of the Association for Computational Linguistics on Human Language Technology: Demonstrations-Volume 4.

Smith, A. E. and Humphreys, M. S. (2006). 'Evaluation of unsupervised semantic mapping of natural language with leximancer concept mapping'. Behavior Research Methods, 38, 262-79.

Steel, R. P. and Ovalle, N. K. (1984). A review and meta-analysis of research on the relationship between behavioral intentions and employee turnover: American Psychological Association.

Szulanski, G. (1996). 'Exploring internal stickiness: Impediments to the transfer of best practice within the firm'. Strategic Management Journal, 17, 27-43.

Tushman, M. L. (1977). 'Special boundary roles in the innovation process'. Administrative Science Quarterly, 22, 587-605.

Udy, S. H. (1959). 'Reviewed work: Organizations'. American journal of sociology, 65, 222-23.

Van de Ven, A. H. and Poole, M. S. (1995). 'Explaining development and change in organizations'. Academy of Management Review, 20, 510-40.

Van Maanen, J. (1998). 'Qualitative studies of organizations'. Thousand Oaks: Sage.

Villena, V. H., Revilla, E. and Choi, T. Y. (2011). 'The dark side of buyer-supplier relationships: A social capital perspective'. Journal of Operations Management, 29, 561-76. 
Vogel, R. and Güttel, W. H. (2012). 'The dynamic capability view in strategic management: A bibliometric review'. International Journal of Management Reviews, 15, 426-46.

Waltman, L. (2016). 'A review of the literature on citation impact indicators'. Journal of Informetrics, 10, 365-91.

Walton, R. E. and Dutton, J. M. (1969). 'The management of interdepartmental conflict: A model and review'. Administrative Science Quarterly, 14, 73-84.

Weick, K. E. (2017). 'Evolving reactions: 60 years with March and Simon's 'organizations”'. Journal of Management Studies, forthcoming.

Wiersema, M. F. and Bantel, K. A. (1992). 'Top management team demography and corporate strategic change'. Academy of Management journal, 35, 91-121.

Wilden, R., Akaka, M. A., Karpen, I. O. and Hohberger, J. (2017). 'The evolution and prospects of service-dominant logic'. Journal of Service Research, 20, 345-61.

Wilden, R., Devinney, T. M. and Dowling, G. R. (2016). 'The architecture of dynamic capability research identifying the building blocks of a configurational approach'. Academy of Management Annals, 10, 997-1076.

Wilden, R., Hohberger, J., Devinney, T. M. and Lavie, D. (2018). 'Revisiting James March (1991): Whither exploration and exploitation?'. Strategic Organization, 16, 352-69.

Williamson, O. E. (1981). 'The economics of organization: The transaction cost approach'. American Journal of Sociology, 87, 548-77.

Wooldridge, B., Schmid, T. and Floyd, S. W. (2008). 'The middle management perspective on strategy process: Contributions, synthesis, and future research'. Journal of Management, 34, $1190-221$. 
Zollo, M. and Winter, S. (2002). 'Deliberate learning and the evolution of dynamic capabilities'. Organization Science, 13, 339-51.

Zupic, I. and Čater, T. (2015). 'Bibliometric methods in management and organization'. Organizational Research Methods, 18, 429-72.

\footnotetext{
${ }^{\mathrm{i}}$ The Louvain algorithm is a greed optimization technique, which tries to optimize the so-called 'modularity' of communities in each network (Fortunato and Barthelemy, 2007). Thereby, modularity is a quantitative measure for the quality of the division of a network into sub-groups (communities) (Newman, 2004); in our case, groups of related research, which are based on the underlying network structure.

ii The classification of scientific fields is based on the publication classification by WoS and the classification with Business and Economics is based on the $59^{\text {th }}$ edition of the meta-journal ranking by Harzing (2018).
} 


\section{Online Appendix}

Sample

The Scopus database did not list Organizations, and thus it did not provide a suitable alternative for the initial search. Google Scholar (GS) is an alternative data source, which may provide a more comprehensive list of citation data. However, it also includes non-academic work, and the bibliometric quality of the listings is less reliable (e.g., it includes multiple versions of working papers or unpublished work). Finally, it should be noted that despite differences between the publication databases (Mongeon and Paul-Hus, 2016; Waltman, 2016), a recent study by MartínMartín (2018) showed that the correlation between citations counts of the database are relatively high. Additionally, these differences are less relevant for our study as we focus on the most important articles (measured by citation) and not the overall population of articles, for this comparison should be even lower.

Furthermore, we excluded books and book chapters for multiple reasons. First, books often do not undergo an equally strict and rigorous review process as articles in peer-reviewed journals. Second, the historical coverage and the inclusion (directly or indirectly) of books in the academic databases is not as complete and reliable as for articles. Third, and specific to the text mining procedures, abstracts often do not exist or are not retrievable in the case of books and book chapters, which is necessary for text mining analysis (Randhawa et al., 2016). Thus, the inclusion of books would introduce an additional validity threat (Denyer and Tranfield, 2009). Table A1 shows the Top 50 journals, in which $M \& S$ have been cited. To depict the evolution and changes over time, we divided the data into four 15-year periods: 1958-1972, 1973-1987, 19882002, and 2003-2017. When we look at where $M \& S$ has been used, we see that there is also an evolution related to academic outlet. Overall, their work is cited in 1,168 unique journals. This varied from 162 journals citing $M \& S$ in $1958-1972$ to 647 journals citing it in 2003-2017. In the 
period 1958-1972, Administrative Science Quarterly (42), Human Relations (22), Behavioral Science (22), Journal of Applied Psychology (16), and Management Science (14) dominated the outlets, while by 2002-2017 this changed completely with the dominant outlets being Organization Science (124), Journal of Applied Psychology (76), Strategic Management Journal (71), and Journal of Management (64). Overall, we see a clear change in the number and style of outlets used by academics that relate their work to $M \& S$, with a growing dominance of those working in the strategy and organizational science domains. This change is more noticeable in journals published in the Business and Management category than in Psychology journals. 
Table A1: Top 50 journals with citations to March and Simon (1958) by time period

\begin{tabular}{|c|c|c|c|c|c|c|c|c|c|c|}
\hline \multirow[t]{2}{*}{ Journal title } & \multicolumn{2}{|c|}{$\begin{array}{c}\text { Period 1: } \\
1958 \text { - } 1972\end{array}$} & \multicolumn{2}{|c|}{$\begin{array}{c}\text { Period 2: } \\
1973 \text { - } 1987\end{array}$} & \multicolumn{2}{|c|}{$\begin{array}{c}\text { Period 3: } \\
1988 \text { - 2002 }\end{array}$} & \multicolumn{2}{|c|}{$\begin{array}{c}\text { Period 4: } \\
2003-2017\end{array}$} & \multicolumn{2}{|c|}{$\begin{array}{l}\text { Period 1-4: } \\
1958-2017\end{array}$} \\
\hline & $n$ & $\%$ & $n$ & $\%$ & $n$ & $\%$ & $n$ & $\%$ & $n$ & $\%$ \\
\hline Human Relations & 22 & $14 \%$ & 118 & $29 \%$ & 78 & $18 \%$ & 32 & $5 \%$ & 250 & $21 \%$ \\
\hline Journal of Applied Psychology & 16 & $10 \%$ & 38 & $9 \%$ & 62 & $14 \%$ & 76 & $12 \%$ & 192 & $16 \%$ \\
\hline Administrative Science Quarterly & 42 & $26 \%$ & 92 & $23 \%$ & 43 & $10 \%$ & 13 & $2 \%$ & 190 & $16 \%$ \\
\hline Management Science & 14 & $9 \%$ & 46 & $11 \%$ & 52 & $12 \%$ & 70 & $11 \%$ & 182 & $16 \%$ \\
\hline Academy of Management Journal & 6 & $4 \%$ & 62 & $15 \%$ & 56 & $13 \%$ & 57 & $9 \%$ & 181 & $15 \%$ \\
\hline Organization Science & 0 & $0 \%$ & 0 & $0 \%$ & 57 & $13 \%$ & 124 & $19 \%$ & 181 & $15 \%$ \\
\hline Journal of Management & 0 & $0 \%$ & 14 & $3 \%$ & 72 & $17 \%$ & 64 & $10 \%$ & 150 & $13 \%$ \\
\hline Strategic Management Journal & 0 & $0 \%$ & 14 & $3 \%$ & 54 & $12 \%$ & 71 & $11 \%$ & 139 & $12 \%$ \\
\hline Academy of Management Review & 0 & $0 \%$ & 47 & $12 \%$ & 45 & $10 \%$ & 33 & $5 \%$ & 125 & $11 \%$ \\
\hline Journal of Management Studies & 1 & $1 \%$ & 22 & $5 \%$ & 44 & $10 \%$ & 38 & $6 \%$ & 105 & $9 \%$ \\
\hline Journal of Organizational Behavior & 0 & $0 \%$ & 0 & $0 \%$ & 48 & $11 \%$ & 52 & $8 \%$ & 100 & $9 \%$ \\
\hline Organization Studies & 0 & $0 \%$ & 10 & $2 \%$ & 40 & $9 \%$ & 43 & $7 \%$ & 93 & $8 \%$ \\
\hline Journal of Business Ethics & 0 & $0 \%$ & 0 & $0 \%$ & 20 & $5 \%$ & 50 & $8 \%$ & 70 & $6 \%$ \\
\hline Org. Beh. and Human Decision Processes & 0 & $0 \%$ & 10 & $2 \%$ & 32 & $7 \%$ & 24 & $4 \%$ & 66 & $6 \%$ \\
\hline Human Resource Management & 0 & $0 \%$ & 2 & $0 \%$ & 12 & $3 \%$ & 44 & $7 \%$ & 58 & $5 \%$ \\
\hline Intl. Journal of Technology Management & 0 & $0 \%$ & 0 & $0 \%$ & 24 & $6 \%$ & 33 & $5 \%$ & 57 & $5 \%$ \\
\hline MIS Quarterly & 0 & $0 \%$ & 12 & $3 \%$ & 15 & $3 \%$ & 30 & $5 \%$ & 57 & $5 \%$ \\
\hline IEEE Transactions on Engineering Mgt. & 6 & $4 \%$ & 10 & $2 \%$ & 8 & $2 \%$ & 32 & $5 \%$ & 56 & $5 \%$ \\
\hline Personnel Psychology & 8 & $5 \%$ & 16 & $4 \%$ & 16 & $4 \%$ & 12 & $2 \%$ & 52 & $4 \%$ \\
\hline Behavioral Science & 22 & $14 \%$ & 26 & $6 \%$ & 2 & $0 \%$ & 0 & $0 \%$ & 50 & $4 \%$ \\
\hline Research Policy & 0 & $0 \%$ & 0 & $0 \%$ & 14 & $3 \%$ & 36 & $6 \%$ & 50 & $4 \%$ \\
\hline Journal of Applied Behavioral Science & 2 & $1 \%$ & 30 & $7 \%$ & 5 & $1 \%$ & 12 & $2 \%$ & 49 & $4 \%$ \\
\hline Administration \& Society & 0 & $0 \%$ & 33 & $8 \%$ & 11 & $3 \%$ & 3 & $0 \%$ & 47 & $4 \%$ \\
\hline Information Systems Research & 0 & $0 \%$ & 0 & $0 \%$ & 14 & $3 \%$ & 32 & $5 \%$ & 46 & $4 \%$ \\
\hline Journal of Business Research & 0 & $0 \%$ & 12 & $3 \%$ & 9 & $2 \%$ & 25 & $4 \%$ & 46 & $4 \%$ \\
\hline Technological Forecasting and Social Change & 0 & $0 \%$ & 14 & $3 \%$ & 12 & $3 \%$ & 18 & $3 \%$ & 44 & $4 \%$ \\
\hline Journal of Product Innovation Management & 0 & $0 \%$ & 2 & $0 \%$ & 16 & $4 \%$ & 22 & $3 \%$ & 40 & $3 \%$ \\
\hline Long Range Planning & 0 & $0 \%$ & 6 & $1 \%$ & 4 & $1 \%$ & 28 & $4 \%$ & 38 & $3 \%$ \\
\hline Accounting Organizations and Society & 0 & $0 \%$ & 16 & $4 \%$ & 19 & $4 \%$ & 2 & $0 \%$ & 37 & $3 \%$ \\
\hline Journal of Vocational Behavior & 0 & $0 \%$ & 11 & $3 \%$ & 10 & $2 \%$ & 16 & $2 \%$ & 37 & $3 \%$ \\
\hline European Journal of Operational Research & 0 & $0 \%$ & 10 & $2 \%$ & 20 & $5 \%$ & 6 & $1 \%$ & 36 & $3 \%$ \\
\hline Information \& Management & 0 & $0 \%$ & 6 & $1 \%$ & 18 & $4 \%$ & 12 & $2 \%$ & 36 & $3 \%$ \\
\hline Policy Sciences & 4 & $2 \%$ & 16 & $4 \%$ & 14 & $3 \%$ & 2 & $0 \%$ & 36 & $3 \%$ \\
\hline Public Administration Review & 1 & $1 \%$ & 10 & $2 \%$ & 11 & $3 \%$ & 14 & $2 \%$ & 36 & $3 \%$ \\
\hline American Behavioral Scientist & 0 & $0 \%$ & 24 & $6 \%$ & 10 & $2 \%$ & 0 & $0 \%$ & 34 & $3 \%$ \\
\hline Industrial and Corporate Change & 0 & $0 \%$ & 0 & $0 \%$ & 4 & $1 \%$ & 30 & $5 \%$ & 34 & $3 \%$ \\
\hline Public Administration & 2 & $1 \%$ & 6 & $1 \%$ & 14 & $3 \%$ & 12 & $2 \%$ & 34 & $3 \%$ \\
\hline Technovation & 0 & $0 \%$ & 0 & $0 \%$ & 15 & $3 \%$ & 18 & $3 \%$ & 33 & $3 \%$ \\
\hline Group \& Organization Management & 0 & $0 \%$ & 0 & $0 \%$ & 18 & $4 \%$ & 14 & $2 \%$ & 32 & $3 \%$ \\
\hline Omega-Intl. Journal of Management Science & 0 & $0 \%$ & 20 & $5 \%$ & 8 & $2 \%$ & 4 & $1 \%$ & 32 & $3 \%$ \\
\hline Journal of International Business Studies & 0 & $0 \%$ & 4 & $1 \%$ & 11 & $3 \%$ & 15 & $2 \%$ & 30 & $3 \%$ \\
\hline Journal of Management Information Systems & 0 & $0 \%$ & 0 & $0 \%$ & 6 & $1 \%$ & 24 & $4 \%$ & 30 & $3 \%$ \\
\hline Personnel Review & 0 & $0 \%$ & 6 & $1 \%$ & 4 & $1 \%$ & 20 & $3 \%$ & 30 & $3 \%$ \\
\hline Sociology of Education & 6 & $4 \%$ & 10 & $2 \%$ & 10 & $2 \%$ & 4 & $1 \%$ & 30 & $3 \%$ \\
\hline Journal of Economic Behavior \& Organization & 0 & $0 \%$ & 3 & $1 \%$ & 17 & $4 \%$ & 9 & $1 \%$ & 29 & $2 \%$ \\
\hline Journal of Occupational and Org. Psychology & 0 & $0 \%$ & 0 & $0 \%$ & 6 & $1 \%$ & 22 & $3 \%$ & 28 & $2 \%$ \\
\hline Policy Studies Journal & 0 & $0 \%$ & 20 & $5 \%$ & 4 & $1 \%$ & 4 & $1 \%$ & 28 & $2 \%$ \\
\hline Journal of Mathematical Sociology & 0 & $0 \%$ & 3 & $1 \%$ & 24 & $6 \%$ & 0 & $0 \%$ & 27 & $2 \%$ \\
\hline American Journal of Sociology & 5 & $3 \%$ & 10 & $2 \%$ & 8 & $2 \%$ & 3 & $0 \%$ & 26 & $2 \%$ \\
\hline Intl. Journal of Human Resource Management & 0 & $0 \%$ & 0 & $0 \%$ & 5 & $1 \%$ & 21 & $3 \%$ & 26 & $2 \%$ \\
\hline Nr. of unique citing journals per time period & 162 & $100 \%$ & 401 & $100 \%$ & 433 & $100 \%$ & 647 & $100 \%$ & 1168 & $100 \%$ \\
\hline
\end{tabular}




\section{Coupling analysis}

Coupling analysis is related to co-citation analysis, which measures the proximity between two publications by the frequency with which these are cited by later publications (Small, 1973). Thus, while co-citation analysis measures the similarity between two cited publications, bibliographic coupling measures the proximity of citing publications (Devinney and Hohberger, 2017). This is of particular relevance for this study, as we are interested in the proximity (i.e., distance) of all publications citing $M \& S$ (1958). It is also important to note that coupling is a static approach as the references of analyzed articles will not change; this is different to cocitation analysis, which is considered a dynamic approach, as the frequency with which two publications are cited by future publications can change as new publications appear (Zupic and Čater, 2015). This implies that co-citation analysis is biased against newer publications, which did not have the time to accumulate citations. This is not the case of coupling; which is, therefore, more appropriate when analyzing current research (Vogel and Güttel, 2012; Zupic and Čater, 2015). However, as citation patterns change, it is recommended that coupling is used when examining non-extended time periods (Zupic and Čater, 2015). For this reason, we only show the coupling results for the four time periods rather than aggregating it for the entire 60 years.

Our coupling procedure follows largely the guidelines developed by Zupic and Čater (2015) and its application in recent publications (Devinney and Hohberger, 2017; Vogel and Güttel, 2012). We used the BibExcel software package (Persson et al., 2009) to calculate the proximity scores of the 500 most cited publications in each period.

In order to increase the interpretability and to focus on the most relevant and representative publications, the networks are built on the 500 most cited publications and were 
further pruned using various thresholds on degree range, proximity score and number of citations for each publication (see Table A2). While we intended to use the same threshold across all networks, the volume and structure of the publications in each period are too different; thus, we had to make an adjustment for each period. To further increase the interpretability and to concentrate on the most relevant and representative publications, we further reduced the number of publications in each analysis. Therefore, we created multiple networks for each time-period with varying thresholds for degree range, proximity score and number of citations for each publication. The objective of this process was to exclude documents that are not central to describing the field, but to still provide a meaningful and representative picture of the research (Zupic and Čater, 2015). The volume and structure of the publications in each period are rather different; thus, we had to adjust the thresholds for each period.

Table A2: Threshold values

\begin{tabular}{l|c|c|c|c}
\hline & $\begin{array}{c}\text { Period 1: } \\
\text { 1958-1972 }\end{array}$ & $\begin{array}{c}\text { Period 2: } \\
\text { 1973-1987 }\end{array}$ & $\begin{array}{c}\text { Period 3: } \\
\text { 1988-2002 }\end{array}$ & $\begin{array}{c}\text { Period 4: } \\
\text { 2002-2017 }\end{array}$ \\
\hline Degree Range & 4 & 4 & 3 & 3 \\
Edge weight (proximity score) & 5 & 6 & 8 & 8 \\
Citations & - & 84 & 125 & 55 \\
\hline
\end{tabular}

The subsequent four tables (A3-A5) show a full list of the publication in each cluster (Cl.) across the four periods sorted by the number of citations (Cit.). The tables also include the complete list of centrality measures (closeness, betweenness, and degree centrality) for each period as a whole as well as for each individual cluster. First, we calculated the standardized closeness centrality for each publication with respect to the entire network and the network of each cluster. Closeness centrality represents the total distance of a node (i.e., publication) from all other nodes (Otte and Rousseau, 2002). In the context of a publication network built on proximity scores from coupling, this measure captures the representativeness of a publication for 
its cluster/network. We also calculated the degree centrality and betweenness centrality. Degree centrality is defined as the number of connections of each node and can be interpreted as an alternative measure for representativeness. On the other hand, betweenness centrality is the extent by which the node is positioned on the shortest path between other pairs of nodes in the network (Otte and Rousseau, 2002). It is frequently used to capture boundary spanning activities or brokerage, and in the context of bibliometrics as a measure for interdisciplinarity

(Leydesdorff, 2007).

Table A3: Period 1, 1958-1972

\begin{tabular}{|c|c|c|c|c|c|c|c|c|}
\hline \multirow[b]{2}{*}{ Publication } & \multirow[b]{2}{*}{ Cl. } & \multirow[b]{2}{*}{ Cit. } & \multicolumn{3}{|c|}{ Network } & \multicolumn{3}{|c|}{ Clusters } \\
\hline & & & $\begin{array}{c}\text { Closeness } \\
\text { centr. }\end{array}$ & $\begin{array}{c}\text { Between. } \\
\text { centr. }\end{array}$ & $\begin{array}{c}\text { Degree } \\
\text { cent. }\end{array}$ & $\begin{array}{c}\text { Closeness } \\
\text { centr. }\end{array}$ & $\begin{array}{c}\text { Between. } \\
\text { centr. }\end{array}$ & $\begin{array}{c}\text { Degree } \\
\text { cent. }\end{array}$ \\
\hline Hrebiniak \& Alutto 1972 & 1 & 324 & 0.83 & 0.01 & 4 & 0.83 & 0.70 & 4 \\
\hline Hall et al. 1970 & 1 & 198 & 0.71 & 0.00 & 3 & 0.71 & 0.15 & 3 \\
\hline Hall 1971 & 1 & 150 & 0.71 & 0.00 & 3 & 0.71 & 0.15 & 3 \\
\hline Alutto \& Belasco 1972 & 1 & 89 & 0.50 & 0.00 & 1 & 0.50 & 0.00 & 1 \\
\hline Schneider \& Hall 1971 & 1 & 35 & 0.50 & 0.00 & 2 & 0.50 & 0.00 & 2 \\
\hline Lammers 1969 & 1 & 23 & 0.50 & 0.00 & 1 & 0.50 & 0.00 & 1 \\
\hline Simon 1959 & 2 & 818 & 1.00 & 0.00 & 3 & 1.00 & 0.67 & 3 \\
\hline Isard \& Dacey 1962 & 2 & 13 & 0.75 & 0.00 & 2 & 0.75 & 0.00 & 2 \\
\hline Dahl 1959 & 2 & 13 & 0.60 & 0.00 & 1 & 0.60 & 0.00 & 1 \\
\hline Shubik 1961 & 2 & 10 & 0.75 & 0.00 & 2 & 0.75 & 0.00 & 2 \\
\hline Perrow 1967 & 3 & 1024 & 0.58 & 0.14 & 8 & 0.56 & 0.78 & 5 \\
\hline Collins 1971 & 3 & 313 & 0.38 & 0.00 & 2 & 0.39 & 0.00 & 2 \\
\hline Hage \& Aiken 1969 & 3 & 270 & 0.44 & 0.02 & 2 & 0.50 & 0.50 & 2 \\
\hline Pugh et al. 1963 & 3 & 201 & 0.39 & 0.03 & 2 & 0.41 & 0.22 & 2 \\
\hline Knight 1967 & 3 & 171 & 0.41 & 0.00 & 2 & 0.38 & 0.00 & 1 \\
\hline Helmich \& Brown 1972 & 3 & 154 & 0.25 & 0.00 & 1 & 0.25 & 0.00 & 1 \\
\hline Hage et al. 1971 & 3 & 73 & 0.46 & 0.07 & 4 & 0.41 & 0.39 & 2 \\
\hline Lefton \& Rosengren 1966 & 3 & 63 & 0.38 & 0.00 & 2 & 0.39 & 0.00 & 2 \\
\hline Corwin 1972 & 3 & 48 & 0.33 & 0.03 & 2 & 0.32 & 0.22 & 2 \\
\hline Campbell \& Faber 1961 & 3 & 10 & 0.29 & 0.00 & 1 & 0.30 & 0.00 & 1 \\
\hline Hickson et al. 1971 & 4 & 617 & 0.62 & 0.14 & 9 & 0.89 & 0.67 & 7 \\
\hline Pondy 1967 & 4 & 385 & 0.53 & 0.06 & 6 & 0.67 & 0.25 & 4 \\
\hline Walton \& Dutton 1969 & 4 & 117 & 0.49 & 0.02 & 5 & 0.67 & 0.02 & 4 \\
\hline Schmidt \& Kochan 1972 & 4 & 108 & 0.44 & 0.00 & 4 & 0.67 & 0.02 & 4 \\
\hline Walton et al. 1969 & 4 & 64 & 0.41 & 0.00 & 3 & 0.57 & 0.00 & 3 \\
\hline Lirtzman \& Wahba 1972 & 4 & 24 & 0.39 & 0.00 & 1 & 0.50 & 0.00 & 1 \\
\hline Reeves \& Turner 1972 & 4 & 19 & 0.46 & 0.00 & 2 & 0.50 & 0.00 & 1 \\
\hline Pondy 1966 & 4 & 13 & 0.35 & 0.00 & 1 & 0.42 & 0.00 & 1 \\
\hline Olsen 1972 & 4 & 10 & 0.39 & 0.00 & 1 & 0.50 & 0.00 & 1 \\
\hline Katzell et al. 1961 & 5 & 85 & 0.50 & 0.00 & 1 & 0.50 & 0.00 & 1 \\
\hline Indik 1963 & 5 & 46 & 0.50 & 0.00 & 1 & 0.50 & 0.00 & 1 \\
\hline Parker 1963 & 5 & 26 & 0.75 & 0.00 & 2 & 0.75 & 0.67 & 2 \\
\hline Katzell 1962 & 5 & 14 & 0.75 & 0.00 & 2 & 0.75 & 0.67 & 2 \\
\hline
\end{tabular}


Table A4: Period 2, 1973-1987

\begin{tabular}{|c|c|c|c|c|c|c|c|c|}
\hline \multirow[b]{2}{*}{ Publication } & \multirow[b]{2}{*}{ Cl. } & \multirow[b]{2}{*}{ Cit. } & \multicolumn{3}{|c|}{ Network } & \multicolumn{3}{|c|}{ Clusters } \\
\hline & & & $\begin{array}{c}\text { Closeness } \\
\text { centr. }\end{array}$ & $\begin{array}{c}\text { Between. } \\
\text { centr. }\end{array}$ & $\begin{array}{c}\text { Degree } \\
\text { centr. }\end{array}$ & $\begin{array}{c}\text { Closeness } \\
\text { centr. }\end{array}$ & $\begin{array}{c}\text { Between. } \\
\text { centr. }\end{array}$ & $\begin{array}{c}\text { Degree } \\
\text { centr. }\end{array}$ \\
\hline Daft \& Lengel 1986 & 0 & 2476 & 0.50 & 0.29 & 41 & 0.80 & 0.12 & 12 \\
\hline Daft \& Weick 1984 & 0 & 1575 & 0.37 & 0.00 & 9 & 0.52 & 0.00 & 3 \\
\hline Milliken 1987 & 0 & 613 & 0.38 & 0.01 & 14 & 0.62 & 0.07 & 7 \\
\hline Tushman 1977 & 0 & 514 & 0.29 & 0.00 & 9 & 0.64 & 0.07 & 8 \\
\hline Schoonhoven 1981 & 0 & 370 & 0.37 & 0.00 & 10 & 0.55 & 0.00 & 5 \\
\hline Daft \& Macintosh 1981 & 0 & 340 & 0.38 & 0.01 & 19 & 0.84 & 0.16 & 13 \\
\hline Tushman \& Scanlan 1981 & 0 & 302 & 0.34 & 0.00 & 7 & 0.62 & 0.01 & 7 \\
\hline Argote 1982 & 0 & 254 & 0.35 & 0.00 & 9 & 0.64 & 0.02 & 8 \\
\hline Tushman \& Katz 1980 & 0 & 220 & 0.29 & 0.00 & 6 & 0.55 & 0.00 & 5 \\
\hline Rousseau 1978 & 0 & 156 & 0.28 & 0.00 & 2 & 0.37 & 0.00 & 1 \\
\hline Tushman 1978 & 0 & 154 & 0.34 & 0.00 & 9 & 0.67 & 0.03 & 9 \\
\hline Tushman 1979 & 0 & 153 & 0.38 & 0.02 & 20 & 0.84 & 0.16 & 13 \\
\hline Katz \& Tushman 1979 & 0 & 148 & 0.35 & 0.00 & 8 & 0.62 & 0.01 & 7 \\
\hline Withey et al. 1983 & 0 & 147 & 0.37 & 0.01 & 13 & 0.59 & 0.01 & 6 \\
\hline Ettlie 1983 & 0 & 144 & 0.29 & 0.00 & 3 & 0.46 & 0.00 & 2 \\
\hline Slocum \& Sims 1980 & 0 & 97 & 0.35 & 0.01 & 6 & 0.57 & 0.13 & 5 \\
\hline Cameron 1981 & 0 & 90 & 0.38 & 0.00 & 11 & 0.57 & 0.00 & 5 \\
\hline Dimaggio \& Powell 1983 & 1 & 9219 & 0.40 & 0.02 & 21 & 0.63 & 0.04 & 15 \\
\hline Hambrick \& Mason 1984 & 1 & 2651 & 0.39 & 0.01 & 15 & 0.60 & 0.02 & 12 \\
\hline Dess \& Beard 1984 & 1 & 1148 & 0.42 & 0.06 & 33 & 0.70 & 0.04 & 21 \\
\hline Miller 1983 & 1 & 997 & 0.37 & 0.01 & 14 & 0.56 & 0.02 & 11 \\
\hline Ouchi 1979 & 1 & 989 & 0.35 & 0.00 & 6 & 0.45 & 0.00 & 4 \\
\hline Vandeven 1986 & 1 & 835 & 0.38 & 0.00 & 12 & 0.55 & 0.01 & 8 \\
\hline Prahalad \& Bettis 1986 & 1 & 829 & 0.33 & 0.00 & 9 & 0.52 & 0.00 & 7 \\
\hline Kimberly \& Evanisko 1981 & 1 & 764 & 0.30 & 0.00 & 3 & 0.43 & 0.00 & 3 \\
\hline Hambrick \& Finkelstein & & & & & & & & \\
\hline 1987 & 1 & 551 & 0.41 & 0.02 & 28 & 0.73 & 0.05 & 23 \\
\hline Meyer 1982 & 1 & 545 & 0.36 & 0.01 & 11 & 0.52 & 0.01 & 8 \\
\hline Singh 1986 & 1 & 503 & 0.40 & 0.02 & 20 & 0.60 & 0.02 & 12 \\
\hline Dess \& Davis 1984 & 1 & 499 & 0.32 & 0.00 & 9 & 0.54 & 0.00 & 9 \\
\hline Hedberg et al. 1976 & 1 & 364 & 0.34 & 0.00 & 7 & 0.49 & 0.00 & 4 \\
\hline Miller \& Friesen 1980 & 1 & 356 & 0.39 & 0.01 & 19 & 0.66 & 0.03 & 18 \\
\hline Hrebiniak \& Joyce 1985 & 1 & 341 & 0.41 & 0.02 & 25 & 0.67 & 0.03 & 19 \\
\hline Burgelman 1983 & 1 & 322 & 0.38 & 0.01 & 18 & 0.63 & 0.02 & 16 \\
\hline Miller \& Droge 1986 & 1 & 318 & 0.40 & 0.03 & 22 & 0.64 & 0.02 & 16 \\
\hline Fredrickson 1984 & 1 & 290 & 0.37 & 0.01 & 17 & 0.65 & 0.02 & 17 \\
\hline Nutt 1984 & 1 & 234 & 0.38 & 0.00 & 14 & 0.58 & 0.01 & 10 \\
\hline Singh et al. 1986 & 1 & 226 & 0.47 & 0.20 & 35 & 0.71 & 0.11 & 22 \\
\hline Bourgeois 1980 & 1 & 214 & 0.32 & 0.00 & 7 & 0.51 & 0.00 & 7 \\
\hline Miller 1987 & 1 & 205 & 0.42 & 0.06 & 38 & 0.86 & 0.20 & 31 \\
\hline Meyerson \& Martin 1987 & 1 & 168 & 0.36 & 0.00 & 11 & 0.49 & 0.01 & 9 \\
\hline Fredrickson 1986 & 1 & 167 & 0.41 & 0.02 & 29 & 0.73 & 0.05 & 23 \\
\hline Chenhall \& Morris 1986 & 1 & 157 & 0.36 & 0.00 & 7 & 0.51 & 0.00 & 5 \\
\hline Mckelvey \& Aldrich 1983 & 1 & 156 & 0.39 & 0.02 & 18 & 0.62 & 0.02 & 14 \\
\hline Ring \& Perry 1985 & 1 & 126 & 0.30 & 0.00 & 4 & 0.49 & 0.00 & 4 \\
\hline Boynton \& Zmud 1987 & 1 & 125 & 0.36 & 0.00 & 6 & 0.49 & 0.00 & 5 \\
\hline Quinn 1978 & 1 & 119 & 0.30 & 0.00 & 4 & 0.49 & 0.00 & 4 \\
\hline Gupta 1987 & 1 & 116 & 0.37 & 0.00 & 12 & 0.53 & 0.00 & 8 \\
\hline Sutton 1987 & 1 & 109 & 0.33 & 0.00 & 3 & 0.43 & 0.00 & 3 \\
\hline Ireland et al. 1987 & 1 & 103 & 0.32 & 0.00 & 10 & 0.53 & 0.00 & 8 \\
\hline Huber \& Mcdaniel 1986 & 1 & 101 & 0.38 & 0.01 & 16 & 0.57 & 0.01 & 10 \\
\hline
\end{tabular}




\begin{tabular}{|c|c|c|c|c|c|c|c|c|}
\hline Fredrickson 1985 & 1 & 96 & 0.32 & 0.00 & 8 & 0.53 & 0.00 & 8 \\
\hline Jones 1984 & 1 & 94 & 0.37 & 0.01 & 8 & 0.51 & 0.00 & 5 \\
\hline Miller \& Friesen 1982 & 1 & 93 & 0.40 & 0.01 & 20 & 0.62 & 0.02 & 14 \\
\hline Jones 1983 & 1 & 88 & 0.32 & 0.01 & 7 & 0.52 & 0.00 & 5 \\
\hline Shrivastava \& Grant 1985 & 1 & 85 & 0.33 & 0.00 & 18 & 0.64 & 0.03 & 18 \\
\hline Meyer \& Rowan 1977 & 2 & 6090 & 0.31 & 0.01 & 4 & 0.54 & 0.04 & 3 \\
\hline Ouchi 1977 & 2 & 332 & 0.28 & 0.00 & 4 & 0.52 & 0.02 & 4 \\
\hline Cook 1977 & 2 & 327 & 0.33 & 0.03 & 12 & 0.81 & 0.48 & 10 \\
\hline Benson 1977 & 2 & 289 & 0.29 & 0.00 & 6 & 0.62 & 0.05 & 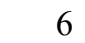 \\
\hline Staw \& Szwajkowski 1975 & 2 & 202 & 0.32 & 0.01 & 6 & 0.57 & 0.09 & 4 \\
\hline Pennings 1975 & 2 & 149 & 0.28 & 0.00 & 5 & 0.59 & 0.02 & 5 \\
\hline Berman 1978 & 2 & 116 & 0.30 & 0.01 & 3 & 0.38 & 0.00 & 2 \\
\hline Khandwalla 1974 & 2 & 111 & 0.30 & 0.00 & 6 & 0.46 & 0.00 & 4 \\
\hline Mckelvey 1975 & 2 & 99 & 0.31 & 0.01 & 8 & 0.62 & 0.06 & 6 \\
\hline Jurkovich 1974 & 2 & 93 & 0.26 & 0.00 & 3 & 0.52 & 0.06 & 3 \\
\hline Comstock \& Scott 1977 & 2 & 92 & 0.36 & 0.04 & 14 & 0.65 & 0.06 & 7 \\
\hline Zeitz 1980 & 2 & 91 & 0.31 & 0.00 & 4 & 0.48 & 0.00 & 2 \\
\hline Georgiou 1973 & 2 & 89 & 0.30 & 0.01 & 4 & 0.54 & 0.00 & 3 \\
\hline Hrebiniak 1974 & 2 & 84 & 0.28 & 0.00 & 7 & 0.65 & 0.06 & 7 \\
\hline Mowday et al. 1979 & 3 & 2158 & 0.23 & 0.00 & 12 & 0.58 & 0.01 & 12 \\
\hline Eisenberger et al. 1986 & 3 & 1831 & 0.22 & 0.00 & 5 & 0.44 & 0.00 & 5 \\
\hline Mobley et al. 1979 & 3 & 807 & 0.28 & 0.02 & 21 & 0.72 & 0.11 & 21 \\
\hline Porter \& Steers 1973 & 3 & 792 & 0.29 & 0.03 & 7 & 0.50 & 0.00 & 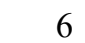 \\
\hline Steers 1977 & 3 & 649 & 0.22 & 0.00 & 10 & 0.52 & 0.00 & 10 \\
\hline Schneider \& Bowen 1985 & 3 & 450 & 0.26 & 0.00 & 3 & 0.45 & 0.00 & 3 \\
\hline Mobley et al. 1978 & 3 & 449 & 0.27 & 0.00 & 14 & 0.63 & 0.02 & 14 \\
\hline Steel \& Ovalle 1984 & 3 & 390 & 0.35 & 0.11 & 23 & 0.76 & 0.13 & 23 \\
\hline Wagner et al. 1984 & 3 & 345 & 0.33 & 0.02 & 10 & 0.57 & 0.00 & 10 \\
\hline Angle \& Perry 1981 & 3 & 343 & 0.27 & 0.01 & 14 & 0.62 & 0.02 & 14 \\
\hline Price \& Mueller 1981 & 3 & 330 & 0.34 & 0.12 & 20 & 0.71 & 0.08 & 20 \\
\hline Rusbult \& Farrell 1983 & 3 & 308 & 0.26 & 0.00 & 3 & 0.51 & 0.00 & 3 \\
\hline Bateman \& Strasser 1984 & 3 & 290 & 0.27 & 0.03 & 19 & 0.69 & 0.09 & 19 \\
\hline Arnold \& Feldman 1982 & 3 & 238 & 0.27 & 0.00 & 14 & 0.63 & 0.02 & 14 \\
\hline Clegg 1983 & 3 & 217 & 0.27 & 0.00 & 10 & 0.53 & 0.01 & 10 \\
\hline Farrell 1983 & 3 & 203 & 0.26 & 0.00 & 4 & 0.48 & 0.00 & 4 \\
\hline Stevens et al. 1978 & 3 & 183 & 0.22 & 0.00 & 10 & 0.52 & 0.00 & 10 \\
\hline Stumpf et al. 1983 & 3 & 180 & 0.26 & 0.00 & 3 & 0.47 & 0.00 & 3 \\
\hline Decotiis \& Summers 1987 & 3 & 178 & 0.27 & 0.01 & 16 & 0.64 & 0.04 & 16 \\
\hline Jamal 1984 & 3 & 159 & 0.27 & 0.00 & 6 & 0.55 & 0.01 & 6 \\
\hline Hackett \& Guion 1985 & 3 & 155 & 0.27 & 0.00 & 6 & 0.53 & 0.00 & 6 \\
\hline Hom et al. 1984 & 3 & 138 & 0.34 & 0.07 & 18 & 0.68 & 0.06 & 18 \\
\hline Cheney 1983 & 3 & 136 & 0.22 & 0.00 & 9 & 0.47 & 0.00 & 9 \\
\hline Abelson \& Baysinger 1984 & 3 & 135 & 0.42 & 0.36 & 7 & 0.49 & 0.00 & 5 \\
\hline Jackofsky 1984 & 3 & 124 & 0.33 & 0.02 & 12 & 0.59 & 0.01 & 12 \\
\hline Farrell \& Rusbult 1981 & 3 & 123 & 0.28 & 0.03 & 23 & 0.76 & 0.15 & 23 \\
\hline Mowday et al. 1984 & 3 & 122 & 0.26 & 0.00 & 6 & 0.49 & 0.00 & 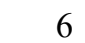 \\
\hline Miller et al. 1979 & 3 & 118 & 0.26 & 0.00 & 5 & 0.49 & 0.00 & 5 \\
\hline Angle \& Perry 1983 & 3 & 116 & 0.22 & 0.00 & 11 & 0.52 & 0.01 & 11 \\
\hline Muchinsky \& Morrow 1980 & 3 & 115 & 0.28 & 0.01 & 17 & 0.64 & 0.04 & 17 \\
\hline Koch \& Steers 1978 & 3 & 111 & 0.27 & 0.00 & 9 & 0.57 & 0.00 & 9 \\
\hline Randall 1987 & 3 & 92 & 0.22 & 0.00 & 8 & 0.50 & 0.00 & 8 \\
\hline Hunt et al. 1985 & 3 & 89 & 0.27 & 0.01 & 13 & 0.58 & 0.02 & 13 \\
\hline Sheridan \& Abelson 1983 & 3 & 86 & 0.27 & 0.00 & 8 & 0.57 & 0.00 & 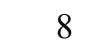 \\
\hline Martin 1979 & 3 & 84 & 0.27 & 0.00 & 7 & 0.54 & 0.00 & 7 \\
\hline Williamson 1981 & 4 & 1438 & 0.33 & 0.02 & 11 & 0.47 & 0.20 & 5 \\
\hline March \& Olsen 1984 & 4 & 954 & 0.35 & 0.00 & 10 & 0.43 & 0.03 & 1 \\
\hline
\end{tabular}




\begin{tabular}{lrr|rrr|rrr} 
March \& Shapira 1987 & 4 & 896 & 0.34 & 0.01 & 7 & 0.41 & 0.02 & 5 \\
Simon 1979 & 4 & 749 & 0.26 & 0.00 & 3 & 0.43 & 0.06 & 3 \\
Feldman \& March 1981 & 4 & 618 & 0.38 & 0.01 & 10 & 0.46 & 0.03 & 6 \\
Schoemaker 1982 & 4 & 576 & 0.31 & 0.01 & 8 & 0.51 & 0.17 & 8 \\
Kiesler \& Sproull 1982 & 4 & 447 & 0.31 & 0.02 & 9 & 0.52 & 0.28 & 8 \\
Levinthal \& March 1981 & 4 & 366 & 0.34 & 0.00 & 5 & 0.43 & 0.00 & 4 \\
Gioia \& Poole 1984 & 4 & 264 & 0.25 & 0.01 & 3 & 0.40 & 0.15 & 3 \\
Starbuck 1983 & 4 & 256 & 0.31 & 0.00 & 6 & 0.43 & 0.03 & 4 \\
Neale \& Bazerman 1985 & 4 & 215 & 0.26 & 0.00 & 2 & 0.35 & 0.00 & 2 \\
Faulkner \& Anderson 1987 & 4 & 209 & 0.35 & 0.00 & 3 & 0.30 & 0.00 & 1 \\
Nelson 1981 & 4 & 202 & 0.31 & 0.00 & 5 & 0.39 & 0.13 & 3 \\
Masuch 1985 & 4 & 143 & 0.32 & 0.00 & 8 & 0.37 & 0.00 & 3 \\
Steers \& Porter 1974 & 4 & 124 & 0.33 & 0.03 & 3 & 0.25 & 0.00 & 1 \\
Williamson 1980 & 4 & 120 & 0.26 & 0.00 & 2 & 0.32 & 0.00 & 1 \\
Lord \& Kernan 1987 & 4 & 114 & 0.23 & 0.00 & 2 & 0.31 & 0.00 & 2 \\
Cowan 1986 & 4 & 105 & 0.35 & 0.01 & 5 & 0.35 & 0.00 & 2 \\
Bendor \& Moe 1985 & 4 & 91 & 0.29 & 0.00 & 2 & 0.38 & 0.00 & 2 \\
Miner 1984 & 4 & 90 & 0.37 & 0.05 & 8 & 0.33 & 0.12 & 3 \\
Lord \& Hanges 1987 & 4 & 89 & 0.28 & 0.02 & 3 & 0.33 & 0.06 & 3 \\
Miner 1987 & 4 & 86 & 0.35 & 0.00 & 5 & 0.43 & 0.09 & 3 \\
Lant \& Montgomery 1987 & 4 & 84 & 0.36 & 0.00 & 8 & 0.40 & 0.00 & 4 \\
\hline
\end{tabular}


Table A5: Period 3, 1988-2002

\begin{tabular}{|c|c|c|c|c|c|c|c|c|}
\hline \multirow[b]{2}{*}{ Publication } & \multirow[b]{2}{*}{ Cl. } & \multirow[b]{2}{*}{ Cit. } & \multicolumn{3}{|c|}{ Network } & \multicolumn{3}{|c|}{ Clusters } \\
\hline & & & $\begin{array}{l}\text { Closeness } \\
\text { centr. }\end{array}$ & $\begin{array}{c}\text { Between. } \\
\text { centr. }\end{array}$ & $\begin{array}{l}\text { Degree } \\
\text { centr. }\end{array}$ & $\begin{array}{c}\text { Closeness } \\
\text { centr. }\end{array}$ & $\begin{array}{c}\text { Between. } \\
\text { centr. }\end{array}$ & $\begin{array}{l}\text { Degree } \\
\text { centr. }\end{array}$ \\
\hline Oldham \& Cummings 1996 & 0 & 915 & 0.21 & 0.00 & 1 & 0.26 & 0.00 & 1 \\
\hline Eisenhardt \& Zbaracki & 0 & 409 & & & & & & 4 \\
\hline $\begin{array}{l}1992 \\
\text { Dean \& Bowen } 1994\end{array}$ & $\begin{array}{l}0 \\
0\end{array}$ & $\begin{array}{l}409 \\
333\end{array}$ & $\begin{array}{l}0.39 \\
0.38\end{array}$ & $\begin{array}{l}0.00 \\
0.01\end{array}$ & $\begin{array}{l}9 \\
6\end{array}$ & $\begin{array}{r}0.47 \\
0.48\end{array}$ & $\begin{array}{l}0.00 \\
0.01\end{array}$ & $\begin{array}{l}4 \\
5\end{array}$ \\
\hline Katz \& Gartner 1988 & 0 & 314 & 0.40 & 0.00 & 9 & 0.50 & 0.00 & 4 \\
\hline Dean \& Sharfman 1996 & 0 & 297 & 0.42 & 0.01 & 10 & 0.49 & 0.01 & 5 \\
\hline Miller 1991 & 0 & 295 & 0.46 & 0.02 & 21 & 0.60 & 0.05 & 11 \\
\hline Tan \& Litschert 1994 & 0 & 273 & 0.39 & 0.00 & 8 & 0.55 & 0.01 & 7 \\
\hline Jaworski 1988 & 0 & 265 & 0.35 & 0.00 & 4 & 0.43 & 0.00 & 3 \\
\hline Bensaou \& Venkatraman & & & & & & & & \\
\hline 1995 & 0 & 232 & 0.44 & 0.05 & 15 & 0.63 & 0.11 & 13 \\
\hline Govindarajan 1988 & 0 & 222 & 0.37 & 0.00 & 8 & 0.56 & 0.05 & 8 \\
\hline Snell 1992 & 0 & 219 & 0.37 & 0.00 & 5 & 0.52 & 0.02 & 5 \\
\hline Boyd et al. 1993 & 0 & 197 & 0.43 & 0.02 & 14 & 0.57 & 0.03 & 9 \\
\hline Smith et al. 1991 & 0 & 191 & 0.42 & 0.03 & 17 & 0.63 & 0.12 & 11 \\
\hline Castrogiovanni 1991 & 0 & 189 & 0.44 & 0.01 & 16 & 0.57 & 0.02 & 9 \\
\hline Boyacigiller 1990 & 0 & 184 & 0.34 & 0.00 & 4 & 0.46 & 0.00 & 4 \\
\hline Sharfman \& Dean 1991 & 0 & 167 & 0.42 & 0.01 & 12 & 0.57 & 0.03 & 9 \\
\hline Miller 1992 & 0 & 160 & 0.55 & 0.21 & 38 & 0.77 & 0.39 & 18 \\
\hline Barki et al. 2001 & 0 & 149 & 0.37 & 0.00 & 4 & 0.51 & 0.00 & 4 \\
\hline Larsson \& Bowen 1989 & 0 & 144 & 0.37 & 0.00 & 5 & 0.51 & 0.01 & 5 \\
\hline Wally \& Baum 1994 & 0 & 142 & 0.39 & 0.00 & 7 & 0.49 & 0.01 & 5 \\
\hline Geletkanycz 1997 & 0 & 139 & 0.39 & 0.00 & 7 & 0.46 & 0.00 & 4 \\
\hline Gresov 1989 & 0 & 134 & 0.38 & 0.00 & 5 & 0.52 & 0.00 & 5 \\
\hline Thomas et al. 1991 & 0 & 129 & 0.35 & 0.00 & 6 & 0.44 & 0.00 & 4 \\
\hline West \& Farr 1989 & 0 & 126 & 0.27 & 0.02 & 2 & 0.35 & 0.08 & 2 \\
\hline Slappendel 1996 & 0 & 126 & 0.37 & 0.03 & 3 & 0.51 & 0.16 & 3 \\
\hline Sitkin \& Pablo 1992 & 1 & 530 & 0.28 & 0.00 & 3 & 0.60 & 0.00 & 3 \\
\hline Haunschild \& Miner 1997 & 1 & 419 & 0.36 & 0.01 & 3 & 0.38 & 0.00 & 1 \\
\hline Bromiley 1991 & 1 & 404 & 0.33 & 0.00 & 5 & 0.67 & 0.13 & 4 \\
\hline Greve 1998 & 1 & 337 & 0.38 & 0.03 & 8 & 0.75 & 0.53 & 4 \\
\hline March \& Shapira 1992 & 1 & 258 & 0.34 & 0.00 & 5 & 0.67 & 0.13 & 4 \\
\hline Baum et al. 2000 & 1 & 234 & 0.30 & 0.00 & 2 & 0.55 & 0.33 & 2 \\
\hline Dyer \& Singh 1998 & 2 & 3243 & 0.30 & 0.02 & 8 & 0.52 & 0.23 & 8 \\
\hline Szulanski 1996 & 2 & 2460 & 0.27 & 0.00 & 4 & 0.45 & 0.02 & 4 \\
\hline Grant 1996 & 2 & 1719 & 0.27 & 0.00 & 3 & 0.48 & 0.01 & 3 \\
\hline Zollo \& Winter 2002 & 2 & 1559 & 0.34 & 0.06 & 10 & 0.53 & 0.29 & 10 \\
\hline Dyer \& Nobeoka 2000 & 2 & 1085 & 0.26 & 0.00 & 3 & 0.44 & 0.00 & 3 \\
\hline Gulati \& Singh 1998 & 2 & 794 & 0.29 & 0.01 & 6 & 0.45 & 0.09 & 6 \\
\hline Rosenkopf \& Nerkar 2001 & 2 & 736 & 0.32 & 0.03 & 9 & 0.58 & 0.32 & 9 \\
\hline Fleming 2001 & 2 & 542 & 0.25 & 0.00 & 4 & 0.41 & 0.01 & 4 \\
\hline Zaheer \& Venkatraman & & & & & & & & \\
\hline 1995 & 2 & 539 & 0.35 & 0.04 & 7 & 0.40 & 0.12 & 6 \\
\hline Szulanski 2000 & 2 & 512 & 0.26 & 0.00 & 4 & 0.41 & 0.01 & 4 \\
\hline Edmondson et al. 2001 & 2 & 508 & 0.32 & 0.01 & 4 & 0.40 & 0.02 & 4 \\
\hline Feldman 2000 & 2 & 487 & 0.42 & 0.08 & 6 & 0.37 & 0.09 & 3 \\
\hline Williamson 1999 & 2 & 459 & 0.28 & 0.00 & 5 & 0.46 & 0.09 & 5 \\
\hline Zollo et al. 2002 & 2 & 378 & 0.27 & 0.00 & 5 & 0.48 & 0.10 & 5 \\
\hline Benner 2002 & 2 & 371 & 0.32 & 0.02 & 8 & 0.48 & 0.08 & 7 \\
\hline Orlikowski \& Yates 1994 & 2 & 361 & 0.31 & 0.00 & 2 & 0.27 & 0.00 & 1 \\
\hline Fleming \& Sorenson 2001 & 2 & 316 & 0.27 & 0.01 & 4 & 0.41 & 0.09 & 4 \\
\hline
\end{tabular}




\begin{tabular}{|c|c|c|c|c|c|c|c|}
\hline Hart \& Saunders 1997 & 2 & 259 & 0.31 & 0.00 & 3 & 0.33 & 0.00 \\
\hline Nelson \& Winter 2002 & 2 & 257 & 0.26 & 0.00 & 3 & 0.38 & 0.01 \\
\hline Williamson 1998 & 2 & 245 & 0.28 & 0.00 & 3 & 0.36 & 0.00 \\
\hline Kogut \& Kulatilaka 2001 & 2 & 175 & 0.40 & 0.06 & 4 & 0.43 & 0.00 \\
\hline Hargadon 2002 & 2 & 162 & 0.31 & 0.01 & 2 & 0.29 & 0.00 \\
\hline Mitchell \& Singh 1996 & 2 & 158 & 0.34 & 0.03 & 6 & 0.40 & 0.01 \\
\hline Sutcliffe \& Zaheer 1998 & 2 & 138 & 0.35 & 0.00 & 3 & 0.29 & 0.00 \\
\hline Eisenberger et al. 1990 & 3 & 751 & 0.60 & 0.00 & 5 & 0.60 & 0.58 \\
\hline Settoon et al. 1996 & 3 & 620 & 0.43 & 0.00 & 3 & 0.43 & 0.00 \\
\hline Mitchell et al. 2001 & 3 & 548 & 0.50 & 0.00 & 4 & 0.50 & 0.17 \\
\hline Eisenberger et al. 1997 & 3 & 395 & 0.43 & 0.00 & 3 & 0.43 & 0.00 \\
\hline Trevor 2001 & 3 & 196 & 0.38 & 0.00 & 3 & 0.38 & 0.00 \\
\hline Hom \& Kinicki 2001 & 3 & 163 & 0.38 & 0.00 & 3 & 0.38 & 0.00 \\
\hline Jaros et al. 1993 & 3 & 162 & 0.60 & 0.00 & 3 & 0.60 & 0.56 \\
\hline Coyle-Shapiro 2002 & 3 & 156 & 0.41 & 0.00 & 2 & 0.41 & 0.00 \\
\hline Lynch et al. 1999 & 3 & 141 & 0.45 & 0.00 & 4 & 0.45 & 0.03 \\
\hline Chen et al. 1998 & 3 & 139 & 0.50 & 0.00 & 4 & 0.50 & 0.17 \\
\hline Henderson \& Clark 1990 & 4 & 2392 & 0.38 & 0.00 & 4 & 0.41 & 0.00 \\
\hline Walsh \& Ungson 1991 & 4 & 856 & 0.45 & 0.06 & 19 & 0.56 & 0.14 \\
\hline Vandeven \& Poole 1995 & 4 & 799 & 0.32 & 0.00 & 3 & 0.35 & 0.00 \\
\hline Ocasio 1997 & 4 & 796 & 0.39 & 0.03 & 8 & 0.49 & 0.02 \\
\hline Wiersema \& Bantel 1992 & 4 & 739 & 0.43 & 0.03 & 17 & 0.53 & 0.06 \\
\hline Gersick 1991 & 4 & 638 & 0.38 & 0.00 & 5 & 0.48 & 0.02 \\
\hline \multirow{2}{*}{\multicolumn{8}{|c|}{$\begin{array}{l}\text { Finkelstein \& Hambrick } \\
1990\end{array}$}} \\
\hline & & & & & & & \\
\hline Levinthal 1997 & 4 & 589 & 0.44 & 0.06 & 8 & 0.48 & 0.03 \\
\hline Orton \& Weick 1990 & 4 & 556 & 0.37 & 0.00 & 3 & 0.36 & 0.00 \\
\hline Hambrick et al. 1996 & 4 & 537 & 0.38 & 0.00 & 9 & 0.48 & 0.01 \\
\hline Gavetti \& Levinthal 2000 & 4 & 523 & 0.35 & 0.01 & 3 & 0.37 & 0.00 \\
\hline Porac et al. 1989 & 4 & 500 & 0.33 & 0.00 & 4 & 0.41 & 0.01 \\
\hline Davis 1991 & 4 & 493 & 0.26 & 0.00 & 1 & 0.29 & 0.00 \\
\hline Zenger \& Lawrence 1989 & 4 & 434 & 0.30 & 0.00 & 2 & 0.35 & 0.00 \\
\hline Hayward \& Hambrick 1997 & 4 & 421 & 0.34 & 0.00 & 2 & 0.42 & 0.00 \\
\hline Orlikowski \& Gash 1994 & 4 & 402 & 0.32 & 0.00 & 4 & 0.37 & 0.00 \\
\hline Barr et al. 1992 & 4 & 400 & 0.42 & 0.01 & 7 & 0.49 & 0.02 \\
\hline Vandeven 1992 & 4 & 390 & 0.37 & 0.00 & 7 & 0.43 & 0.01 \\
\hline Hambrick et al. 1993 & 4 & 361 & 0.38 & 0.00 & 7 & 0.46 & 0.00 \\
\hline Lant et al. 1992 & 4 & 345 & 0.47 & 0.07 & 26 & 0.66 & 0.21 \\
\hline Hill \& Jones 1992 & 4 & 341 & 0.35 & 0.02 & 2 & 0.41 & 0.05 \\
\hline Porac \& Thomas 1990 & 4 & 322 & 0.34 & 0.00 & 5 & 0.40 & 0.00 \\
\hline Miller 1993 & 4 & 314 & 0.53 & 0.15 & 29 & 0.66 & 0.22 \\
\hline Child 1997 & 4 & 297 & 0.38 & 0.00 & 4 & 0.41 & 0.00 \\
\hline \multirow{2}{*}{\multicolumn{8}{|c|}{$\begin{array}{l}\text { Carpenter \& Fredrickson } \\
2001\end{array}$}} \\
\hline & & & & & & & \\
\hline Burns \& Wholey 1993 & 4 & 244 & 0.40 & 0.00 & 7 & 0.44 & 0.00 \\
\hline Walsh 1988 & 4 & 224 & 0.34 & 0.00 & 3 & 0.43 & 0.00 \\
\hline Spender 1996 & 4 & 223 & 0.32 & 0.00 & 2 & 0.38 & 0.00 \\
\hline Boeker 1997 & 4 & 219 & 0.48 & 0.05 & 25 & 0.63 & 0.16 \\
\hline Barnett \& Hansen 1996 & 4 & 199 & 0.37 & 0.00 & 5 & 0.47 & 0.00 \\
\hline Lant \& Mezias 1992 & 4 & 195 & 0.49 & 0.07 & 20 & 0.59 & 0.07 \\
\hline Daveni \& Macmillan 1990 & 4 & 194 & 0.36 & 0.00 & 3 & 0.43 & 0.00 \\
\hline Lant 1992 & 4 & 173 & 0.35 & 0.00 & 3 & 0.42 & 0.00 \\
\hline Miller \& Chen 1996 & 4 & 160 & 0.44 & 0.02 & 15 & 0.53 & 0.04 \\
\hline Miner et al. 1990 & 4 & 159 & 0.45 & 0.02 & 17 & 0.56 & 0.06 \\
\hline Kilduff et al. 2000 & 4 & 158 & 0.33 & 0.00 & 5 & 0.41 & 0.00 \\
\hline
\end{tabular}


Fredrickson \& Iaquinto 1989

Wiersema \& Bird 1993

Huff et al. 1992

Lord \& Maher 1990

Carley 1992

\begin{tabular}{ll|rrr|rrr}
4 & 154 & 0.43 & 0.00 & 14 & 0.51 & 0.00 & 8 \\
4 & 152 & 0.35 & 0.00 & 6 & 0.47 & 0.01 & 6 \\
4 & 151 & 0.44 & 0.02 & 17 & 0.58 & 0.07 & 14 \\
4 & 150 & 0.34 & 0.00 & 3 & 0.43 & 0.00 & 3 \\
4 & 127 & 0.43 & 0.01 & 10 & 0.49 & 0.02 & 6 \\
\hline
\end{tabular}


Table A5: Period 4, 2003-2017

\begin{tabular}{|c|c|c|c|c|c|c|c|c|}
\hline \multirow[b]{2}{*}{ Publication } & \multirow[b]{2}{*}{ Cl. } & \multirow[b]{2}{*}{ Cit. } & \multicolumn{3}{|c|}{ Network } & \multicolumn{3}{|c|}{ Clusters } \\
\hline & & & $\begin{array}{c}\text { Closeness } \\
\text { centr. }\end{array}$ & $\begin{array}{l}\text { Between. } \\
\text { centr. }\end{array}$ & $\begin{array}{l}\text { Degree } \\
\text { centr. }\end{array}$ & $\begin{array}{c}\text { Closeness } \\
\text { centr. }\end{array}$ & $\begin{array}{l}\text { Between. } \\
\text { centr. }\end{array}$ & $\begin{array}{l}\text { Degree } \\
\text { centr. }\end{array}$ \\
\hline Jansen et al. 2006 & 0 & 551 & 0.36 & 0.01 & 8 & 0.44 & 0.00 & 3 \\
\hline Jansen et al. 2005 & 0 & 472 & 0.33 & 0.00 & 11 & 0.52 & 0.01 & 8 \\
\hline Rosenkopf \& Almeida 2003 & 0 & 440 & 0.34 & 0.00 & 13 & 0.54 & 0.00 & 10 \\
\hline Lavie \& Rosenkopf 2006 & 0 & 355 & 0.41 & 0.08 & 33 & 0.68 & 0.10 & 15 \\
\hline Alvarez \& Barney 2007 & 0 & 340 & 0.31 & 0.00 & 5 & 0.47 & 0.00 & 4 \\
\hline Barnett 2007 & 0 & 331 & 0.32 & 0.00 & 5 & 0.49 & 0.02 & 3 \\
\hline Fleming \& Sorenson 2004 & 0 & 289 & 0.33 & 0.00 & 13 & 0.51 & 0.00 & 7 \\
\hline Song et al. 2003 & 0 & 275 & 0.31 & 0.00 & 9 & 0.60 & 0.01 & 9 \\
\hline Hill \& Rothaermel 2003 & 0 & 265 & 0.37 & 0.01 & 17 & 0.61 & 0.04 & 10 \\
\hline \multicolumn{9}{|l|}{ Ramos-Rodriguez \& Ruiz- } \\
\hline Navarro 2004 & 0 & 199 & 0.34 & 0.03 & 18 & 0.63 & 0.13 & 12 \\
\hline Phene et al. 2006 & 0 & 175 & 0.35 & 0.01 & 19 & 0.71 & 0.07 & 16 \\
\hline Mishina et al. 2004 & 0 & 170 & 0.30 & 0.00 & 3 & 0.45 & 0.00 & 2 \\
\hline Nerkar 2003 & 0 & 151 & 0.34 & 0.00 & 17 & 0.64 & 0.02 & 13 \\
\hline Afuah \& Tucci 2012 & 0 & 138 & 0.36 & 0.01 & 26 & 0.69 & 0.07 & 16 \\
\hline Garg et al. 2003 & 0 & 128 & 0.26 & 0.00 & 2 & 0.40 & 0.00 & 2 \\
\hline Monteiro et al. 2008 & 0 & 125 & 0.32 & 0.00 & 6 & 0.48 & 0.01 & 4 \\
\hline Miller et al. 2007 & 0 & 122 & 0.35 & 0.01 & 21 & 0.69 & 0.05 & 15 \\
\hline Wadhwa \& Kotha 2006 & 0 & 120 & 0.37 & 0.01 & 22 & 0.68 & 0.07 & 15 \\
\hline Liao et al. 2003 & 0 & 114 & 0.35 & 0.00 & 7 & 0.49 & 0.01 & 4 \\
\hline Agarwal et al. 2007 & 0 & 96 & 0.39 & 0.04 & 29 & 0.73 & 0.20 & 17 \\
\hline Petersen et al. 2008 & 0 & 85 & 0.35 & 0.00 & 8 & 0.44 & 0.01 & 4 \\
\hline Gruber et al. 2008 & 0 & 81 & 0.32 & 0.00 & 6 & 0.48 & 0.00 & 3 \\
\hline Alvarez \& Barney 2010 & 0 & 69 & 0.32 & 0.00 & 7 & 0.47 & 0.00 & 4 \\
\hline Cattani 2005 & 0 & 65 & 0.38 & 0.01 & 19 & 0.68 & 0.02 & 14 \\
\hline Keil 2004 & 0 & 60 & 0.38 & 0.02 & 28 & 0.60 & 0.01 & 11 \\
\hline Branzei \& Vertinsky 2006 & 0 & 60 & 0.32 & 0.00 & 10 & 0.54 & 0.03 & 9 \\
\hline Miller 2011 & 0 & 60 & 0.31 & 0.01 & 7 & 0.47 & 0.01 & 4 \\
\hline Zahra 2008 & 0 & 58 & 0.31 & 0.00 & 6 & 0.54 & 0.01 & 6 \\
\hline Gibson \& Birkinshaw 2004 & 1 & 792 & 0.36 & 0.23 & 3 & 0.47 & 0.00 & 2 \\
\hline Borgatti \& Cross 2003 & 1 & 582 & 0.36 & 0.01 & 9 & 0.53 & 0.00 & 4 \\
\hline Becker 2004 & 1 & 291 & 0.38 & 0.02 & 25 & 0.87 & 0.11 & 17 \\
\hline Bechky 2006 & 1 & 236 & 0.29 & 0.00 & 3 & 0.45 & 0.00 & 2 \\
\hline \multicolumn{9}{|l|}{ Feldman \& Orlikowski } \\
\hline 2011 & 1 & 214 & 0.35 & 0.01 & 15 & 0.77 & 0.12 & 14 \\
\hline Levinthal \& Rerup 2006 & 1 & 207 & 0.38 & 0.01 & 26 & 0.74 & 0.01 & 13 \\
\hline Pentland \& Feldman 2005 & 1 & 198 & 0.36 & 0.00 & 16 & 0.77 & 0.04 & 14 \\
\hline Farjoun 2010 & 1 & 175 & 0.44 & 0.21 & 30 & 0.74 & 0.08 & 13 \\
\hline Feldman 2003 & 1 & 143 & 0.32 & 0.00 & 13 & 0.69 & 0.00 & 12 \\
\hline Howard-Grenville 2005 & 1 & 136 & 0.35 & 0.00 & 14 & 0.74 & 0.01 & 13 \\
\hline Okhuysen \& Bechky 2009 & 1 & 134 & 0.31 & 0.01 & 4 & 0.51 & 0.01 & 3 \\
\hline Zellmer-Bruhn 2003 & 1 & 118 & 0.38 & 0.04 & 11 & 0.63 & 0.04 & 9 \\
\hline Rerup \& Feldman 2011 & 1 & 117 & 0.38 & 0.01 & 22 & 0.74 & 0.01 & 13 \\
\hline Lewin et al. 2011 & 1 & 111 & 0.42 & 0.08 & 49 & 0.87 & 0.08 & 17 \\
\hline Becker et al. 2005 & 1 & 105 & 0.35 & 0.00 & 14 & 0.74 & 0.01 & 13 \\
\hline Augier \& Teece 2009 & 1 & 105 & 0.32 & 0.00 & 6 & 0.53 & 0.00 & 4 \\
\hline \multicolumn{9}{|l|}{ Parmigiani \& Howard- } \\
\hline Grenville 2011 & 1 & 73 & 0.38 & 0.01 & 24 & 0.83 & 0.05 & 16 \\
\hline D'Adderio 2008 & 1 & 71 & 0.31 & 0.00 & 11 & 0.67 & 0.00 & 11 \\
\hline Choo et al. 2007 & 1 & 67 & 0.36 & 0.00 & 10 & 0.57 & 0.01 & 6 \\
\hline Salvato \& Rerup 2011 & 1 & 66 & 0.37 & 0.00 & 20 & 0.77 & 0.02 & 14 \\
\hline
\end{tabular}




\begin{tabular}{|c|c|c|c|c|c|c|c|c|}
\hline Felin \& Foss 2009 & 1 & 57 & 0.36 & 0.00 & 13 & 0.61 & 0.00 & 8 \\
\hline Allen et al. 2003 & 2 & 374 & 0.18 & 0.05 & 3 & 0.42 & 0.22 & 3 \\
\hline Sun et al. 2007 & 2 & 294 & 0.25 & 0.00 & 6 & 0.41 & 0.01 & 6 \\
\hline Takeuchi et al. 2007 & 2 & 211 & 0.30 & 0.23 & 8 & 0.46 & 0.03 & 7 \\
\hline \multicolumn{9}{|l|}{ Aselage \& Eisenberger } \\
\hline 2003 & 2 & 179 & 0.15 & 0.01 & 3 & 0.31 & 0.04 & 3 \\
\hline Crossley et al. 2007 & 2 & 133 & 0.20 & 0.01 & 8 & 0.49 & 0.04 & 8 \\
\hline Maertz \& Campion 2004 & 2 & 124 & 0.18 & 0.00 & 8 & 0.47 & 0.01 & 8 \\
\hline Felps et al. 2009 & 2 & 122 & 0.20 & 0.00 & 6 & 0.45 & 0.02 & 6 \\
\hline Kehoe \& Wright 2013 & 2 & 120 & 0.25 & 0.00 & 6 & 0.41 & 0.01 & 6 \\
\hline Gittell et al. 2010 & 2 & 110 & 0.29 & 0.10 & 6 & 0.38 & 0.08 & 6 \\
\hline Trevor \& Nyberg 2008 & 2 & 105 & 0.25 & 0.13 & 12 & 0.53 & 0.16 & 12 \\
\hline Boswell et al. 2005 & 2 & 98 & 0.20 & 0.00 & 9 & 0.50 & 0.01 & 9 \\
\hline Gong et al. 2009 & 2 & 95 & 0.25 & 0.01 & 7 & 0.46 & 0.03 & 7 \\
\hline Chen et al. 2005 & 2 & 87 & 0.15 & 0.01 & 3 & 0.31 & 0.04 & 3 \\
\hline Lee et al. 2008 & 2 & 83 & 0.21 & 0.02 & 13 & 0.57 & 0.10 & 13 \\
\hline Carmeli \& Gittell 2009 & 2 & 81 & 0.35 & 0.11 & 4 & 0.28 & 0.00 & 1 \\
\hline Tharenou \& Caulfield 2010 & 2 & 79 & 0.20 & 0.00 & 6 & 0.44 & 0.01 & 6 \\
\hline Van et al. 2004 & 2 & 77 & 0.20 & 0.00 & 7 & 0.48 & 0.00 & 7 \\
\hline Benson et al. 2004 & 2 & 77 & 0.20 & 0.00 & 7 & 0.48 & 0.00 & 7 \\
\hline Moynihan \& Pandey 2008 & 2 & 73 & 0.17 & 0.00 & 2 & 0.38 & 0.00 & 2 \\
\hline Allen et al. 2010 & 2 & 71 & 0.21 & 0.00 & 8 & 0.51 & 0.02 & 8 \\
\hline Griffeth et al. 2005 & 2 & 70 & 0.22 & 0.08 & 10 & 0.60 & 0.33 & 10 \\
\hline Gardner et al. 2011 & 2 & 64 & 0.26 & 0.09 & 8 & 0.52 & 0.16 & 8 \\
\hline Holtom \& O'Neill 2004 & 2 & 63 & 0.21 & 0.01 & 11 & 0.52 & 0.07 & 11 \\
\hline Ramesh \& Gelfand 2010 & 2 & 60 & 0.17 & 0.00 & 4 & 0.39 & 0.00 & 4 \\
\hline Hausknecht \& Trevor 2011 & 2 & 59 & 0.24 & 0.04 & 9 & 0.50 & 0.10 & 9 \\
\hline Sekiguchi et al. 2008 & 2 & 58 & 0.13 & 0.00 & 2 & 0.24 & 0.00 & 2 \\
\hline Gilbert 2005 & 3 & 271 & 0.35 & 0.00 & 16 & 0.60 & 0.01 & 8 \\
\hline Ethiraj \& Levinthal 2004 & 3 & 229 & 0.28 & 0.00 & 3 & 0.41 & 0.00 & 3 \\
\hline Gavetti et al. 2005 & 3 & 187 & 0.33 & 0.00 & 13 & 0.59 & 0.03 & 9 \\
\hline Siggelkow \& Rivkin 2005 & 3 & 179 & 0.33 & 0.00 & 11 & 0.59 & 0.02 & 9 \\
\hline Harris \& Bromiley 2007 & 3 & 138 & 0.31 & 0.00 & 5 & 0.46 & 0.01 & 5 \\
\hline Davis et al. 2009 & 3 & 130 & 0.38 & 0.03 & 22 & 0.60 & 0.04 & 10 \\
\hline Baum \& Dahlin 2007 & 3 & 116 & 0.41 & 0.09 & 24 & 0.67 & 0.06 & 13 \\
\hline Powell et al. 2011 & 3 & 111 & 0.33 & 0.00 & 7 & 0.57 & 0.00 & 7 \\
\hline Ocasio 2011 & 3 & 111 & 0.33 & 0.00 & 9 & 0.55 & 0.00 & 7 \\
\hline Gavetti et al. 2007 & 3 & 109 & 0.39 & 0.03 & 27 & 0.77 & 0.10 & 17 \\
\hline Gilbert 2006 & 3 & 107 & 0.38 & 0.01 & 21 & 0.69 & 0.04 & 13 \\
\hline Greve 2007 & 3 & 102 & 0.38 & 0.05 & 15 & 0.60 & 0.06 & 9 \\
\hline Hodgkinson \& Healey 2011 & 3 & 99 & 0.37 & 0.00 & 17 & 0.59 & 0.01 & 9 \\
\hline Madsen \& Desai 2010 & 3 & 90 & 0.41 & 0.06 & 26 & 0.63 & 0.03 & 11 \\
\hline Gulati \& Puranam 2009 & 3 & 90 & 0.35 & 0.00 & 6 & 0.49 & 0.00 & 4 \\
\hline Greve et al. 2010 & 3 & 86 & 0.34 & 0.01 & 9 & 0.53 & 0.01 & 5 \\
\hline Daniel et al. 2004 & 3 & 85 & 0.29 & 0.00 & 4 & 0.42 & 0.00 & 3 \\
\hline Siggelkow \& Rivkin 2006 & 3 & 76 & 0.34 & 0.00 & 10 & 0.56 & 0.00 & 7 \\
\hline Kaplan 2011 & 3 & 75 & 0.34 & 0.00 & 12 & 0.59 & 0.01 & 9 \\
\hline Rerup 2009 & 3 & 75 & 0.35 & 0.00 & 9 & 0.52 & 0.00 & 5 \\
\hline Gavetti et al. 2012 & 3 & 73 & 0.42 & 0.07 & 45 & 0.86 & 0.17 & 20 \\
\hline Gavetti 2012 & 3 & 73 & 0.43 & 0.08 & 44 & 0.80 & 0.12 & 18 \\
\hline Knudsen \& Levinthal 2007 & 3 & 67 & 0.36 & 0.00 & 16 & 0.65 & 0.03 & 11 \\
\hline Chen 2008 & 3 & 61 & 0.36 & 0.01 & 16 & 0.62 & 0.06 & 10 \\
\hline Haunschild \& Rhee 2004 & 3 & 59 & 0.32 & 0.00 & 4 & 0.51 & 0.00 & 4 \\
\hline Mcevily et al. 2003 & 4 & 418 & 0.27 & 0.00 & 6 & 0.52 & 0.04 & 6 \\
\hline Moran 2005 & 4 & 318 & 0.26 & 0.00 & 4 & 0.47 & 0.02 & 4 \\
\hline Mcevily \& Marcus 2005 & 4 & 298 & 0.36 & 0.07 & 16 & 0.64 & 0.46 & 7 \\
\hline
\end{tabular}




\begin{tabular}{lrr|rrr|lll} 
Taylor \& Greve 2006 & 4 & 232 & 0.29 & 0.03 & 3 & 0.45 & 0.26 & 2 \\
Jehn \& Bendersky 2003 & 4 & 188 & 0.23 & 0.02 & 2 & 0.33 & 0.14 & 2 \\
De \& Saparito 2006 & 4 & 159 & 0.26 & 0.00 & 3 & 0.45 & 0.00 & 3 \\
Bitektine 2011 & 4 & 157 & 0.27 & 0.00 & 3 & 0.39 & 0.00 & 2 \\
Higgins \& Gulati 2003 & 4 & 143 & 0.32 & 0.00 & 5 & 0.40 & 0.01 & 3 \\
Muthusamy \& White 2005 & 4 & 136 & 0.27 & 0.00 & 5 & 0.50 & 0.01 & 5 \\
Villena et al. 2011 & 4 & 133 & 0.31 & 0.03 & 10 & 0.61 & 0.18 & 8 \\
Goo et al. 2009 & 4 & 117 & 0.27 & 0.00 & 5 & 0.50 & 0.01 & 5 \\
Barkema \& Shvyrkov 2007 & 4 & 101 & 0.19 & 0.00 & 1 & 0.25 & 0.00 & 1 \\
Puranam \& Vanneste 2009 & 4 & 80 & 0.24 & 0.00 & 4 & 0.42 & 0.00 & 4 \\
Mitsuhashi \& Greve 2009 & 4 & 66 & 0.31 & 0.00 & 4 & 0.48 & 0.03 & 3 \\
Lee 2007 & 4 & 58 & 0.33 & 0.03 & 11 & 0.58 & 0.28 & 7 \\
\hline
\end{tabular}




\section{Text mining analysis}

The subsequent seven figures represent an alternative (i.e., graphical) representation of the seven book chapters of Organizations. The statistical information is shown in Table I in the main manuscript.

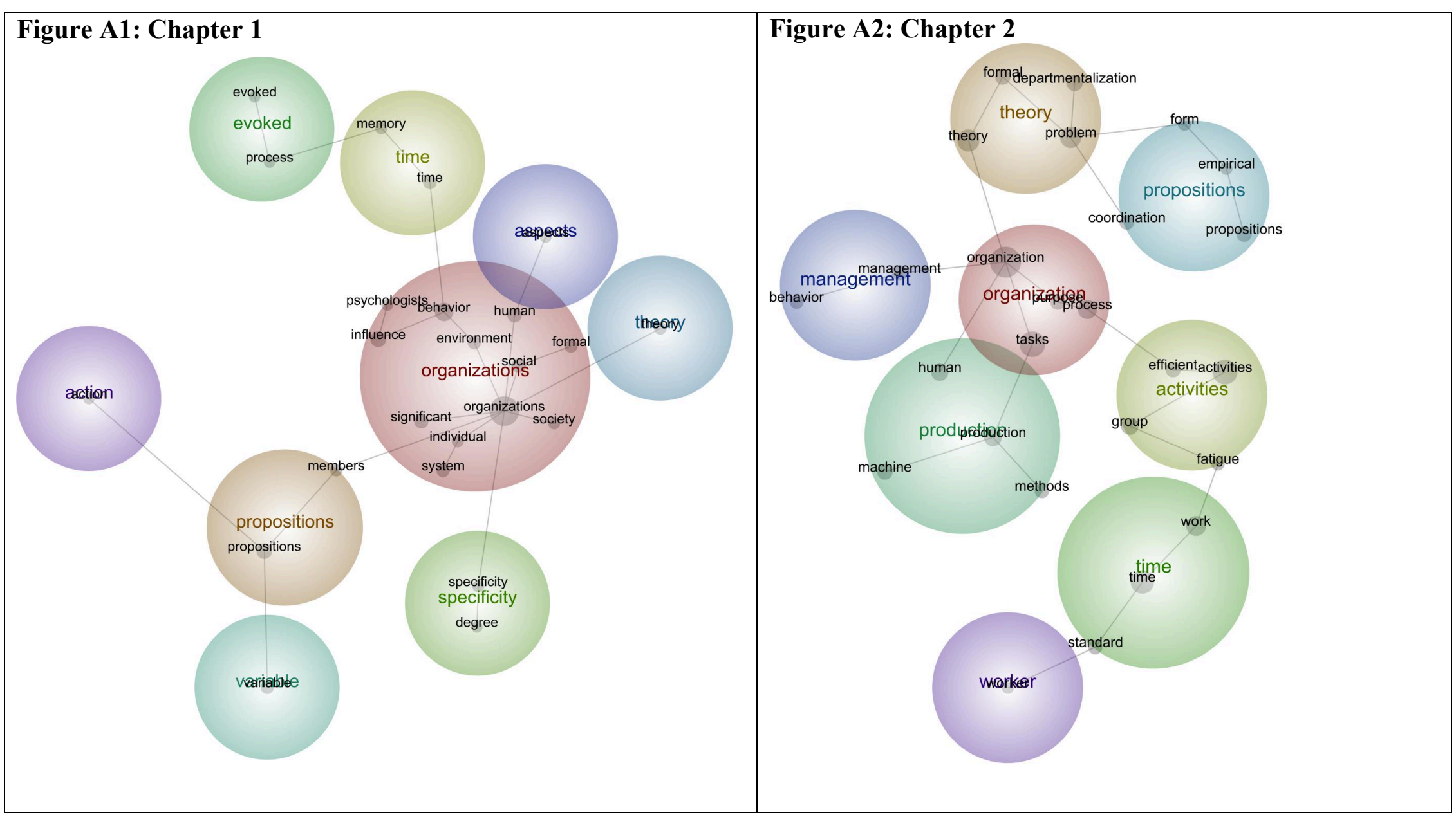




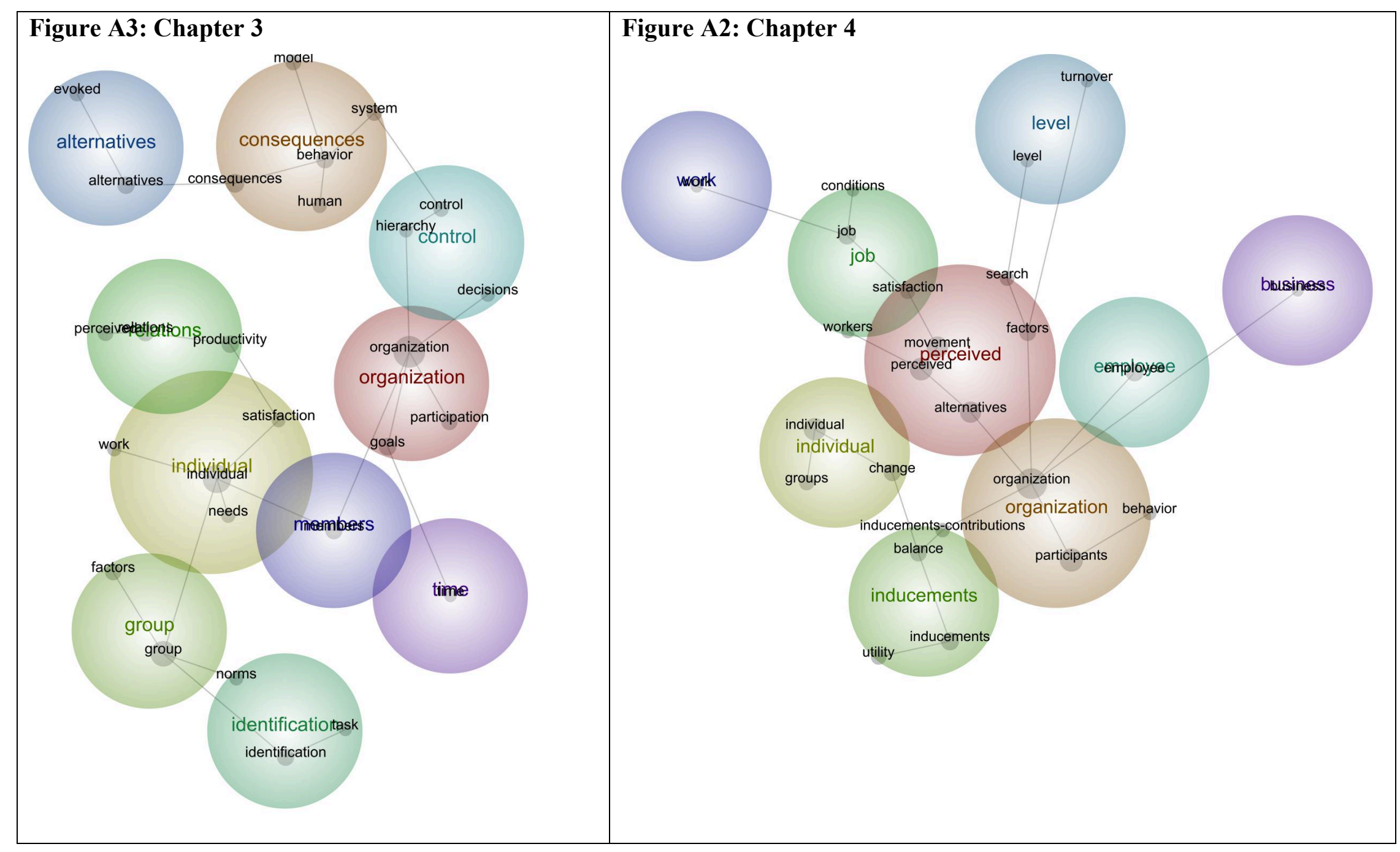




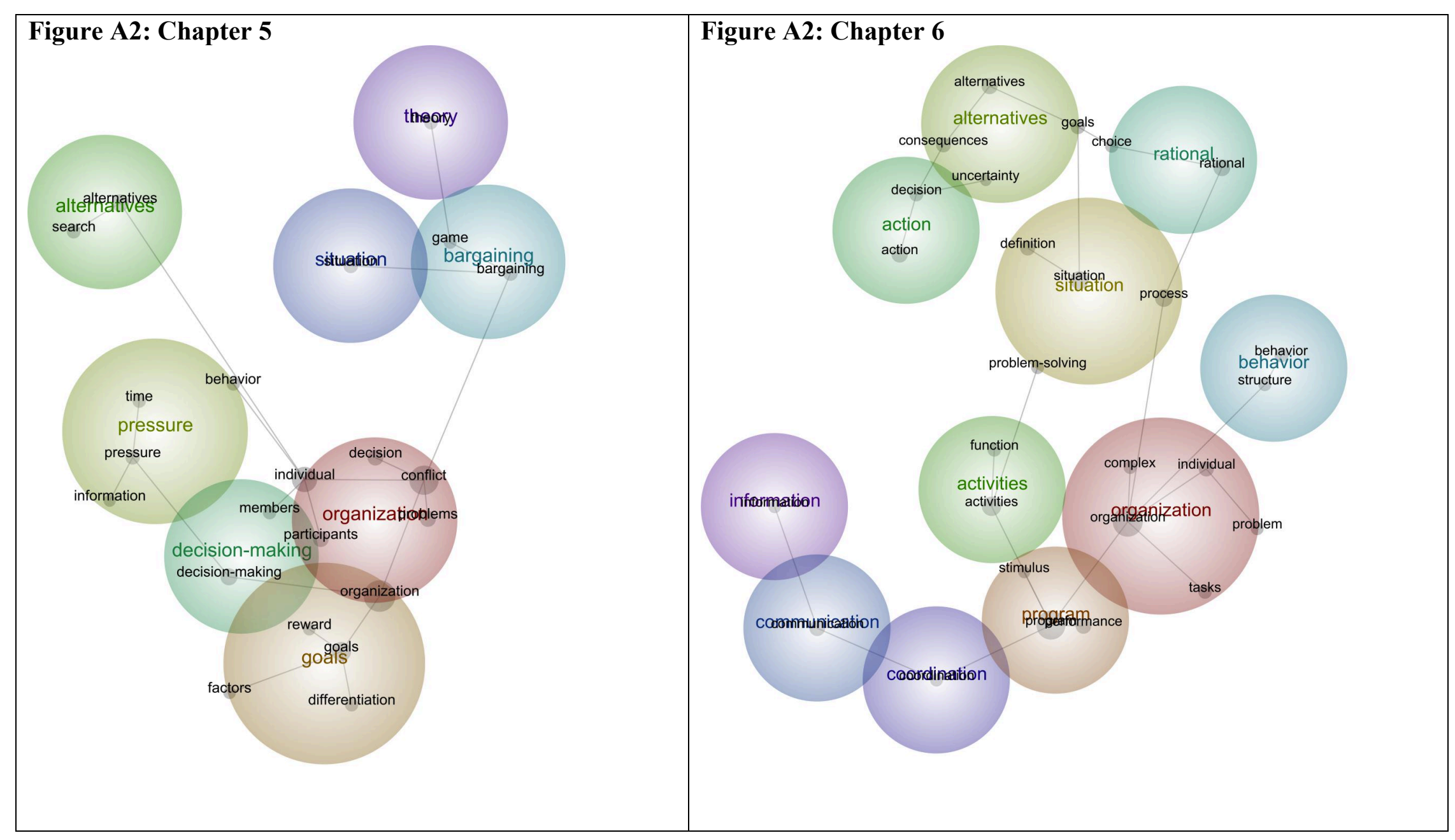




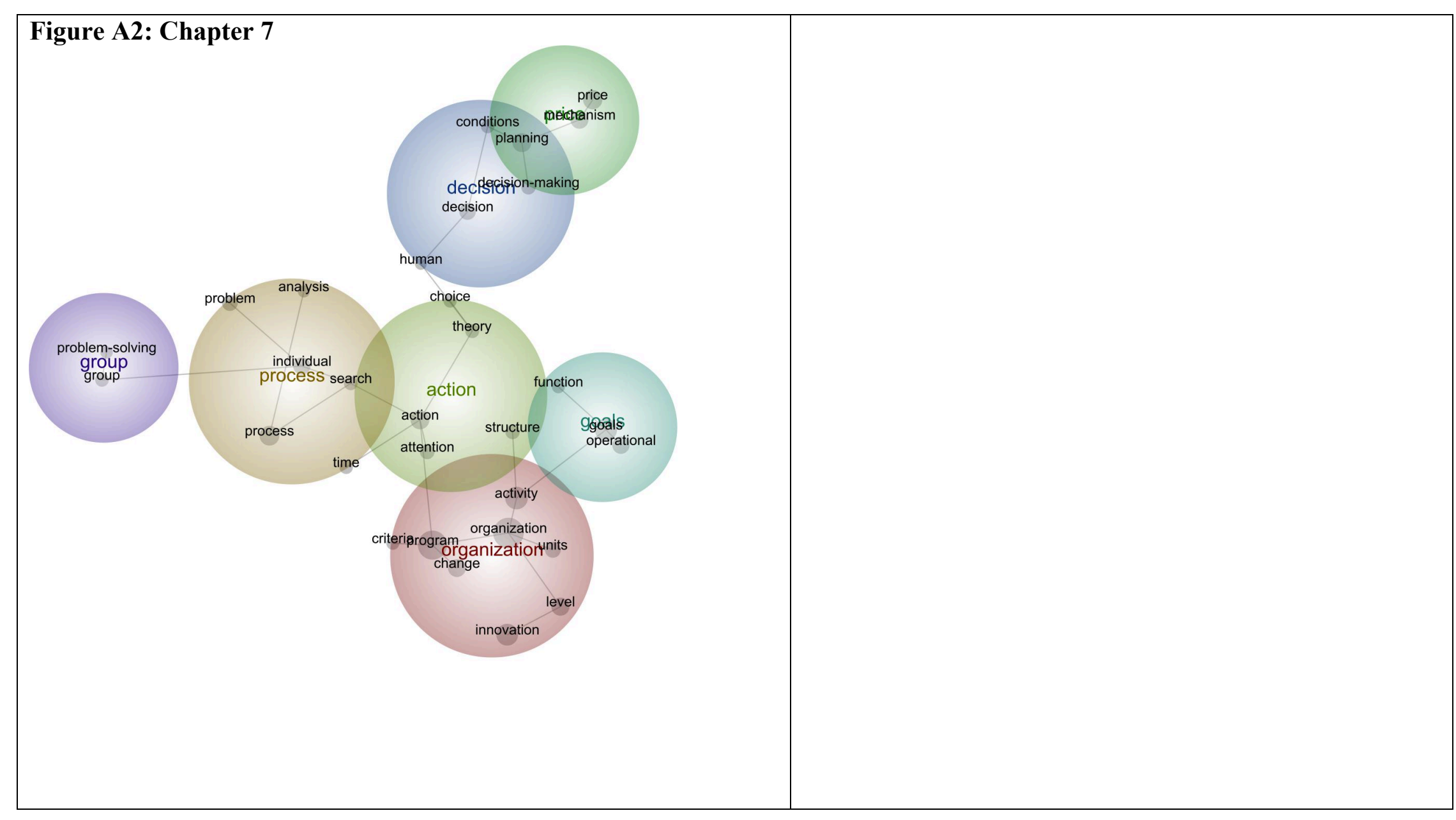

